\title{
Nitrogen stocks and flows in an acid sulfate soil
}

\author{
Markku Yli-Halla $($ D $\cdot$ Seija Virtanen (iD $\cdot$ Kristiina \\ Regina (i) - Peter Österholm (i) - Betty Ehnvall (i) • \\ Jaana Uusi-Kämppä $\mathbb{1}$
}

Received: 20 May 2020 / Accepted: 20 October 2020 / Published online: 6 November 2020

(C) The Author(s) 2020

\begin{abstract}
Besides causing acidification, acid sulfate (AS) soils contain large nitrogen $(\mathrm{N})$ stocks and are a potential source of $\mathrm{N}$ loading to waters and nitrous oxide $\left(\mathrm{N}_{2} \mathrm{O}\right)$ emissions. We quantified the stocks and flows of $\mathrm{N}$, including crop yields, $\mathrm{N}$ leaching, and $\mathrm{N}_{2} \mathrm{O}$ emissions, in a cultivated AS soil in western Finland. We also investigated whether controlled drainage (CD) and sub-irrigation (CDI) to keep the sulfidic horizons inundated can alleviate $\mathrm{N}$ losses. Total $\mathrm{N}$ stock at $0-100 \mathrm{~cm}$ (19.5 $\mathrm{Mg} \mathrm{ha}^{-1}$ ) was smaller than at 100-200 cm (26.6 $\mathrm{Mg} \mathrm{ha}^{-1}$ ), and the mineral $\mathrm{N}$ stock was largest below $170 \mathrm{~cm}$. Annual $\mathrm{N}$ leaching (31-91 kg N ha ${ }^{-1}$ ) plus $\mathrm{N}$ in harvested grain $\left(74-122 \mathrm{~kg} \mathrm{~N} \mathrm{ha}^{-1}\right.$ ) was $148 \%$
\end{abstract}

M. Yli-Halla $(\bowtie)$

Department of Agricultural Sciences, University of Helsinki, P.O. Box 56, 00014 Helsinki, Finland

e-mail: markku.yli-halla@helsinki.fi

S. Virtanen

Drainage Foundation sr., Simonkatu 12 B, 00100 Helsinki, Finland

K. Regina $\cdot$ B. Ehnvall · J. Uusi-Kämppä

Natural Resources Institute Finland, Tietotie 4, 31600 Jokioinen, Finland

P. Österholm

Åbo Akademi University, Akatemiankatu 1, 20500 Turku, Finland

Present Address:

B. Ehnvall

Swedish University of Agricultural Sciences, Skogsmarksgränd 17, 90183 Umeå, Sweden (range 118-189\%) of $\mathrm{N}$ applied in fertilizers (90-125 kg $\mathrm{N} \mathrm{ha}^{-1}$ ) in 2011-2017, suggesting substantial $\mathrm{N}$ supply from soil reserves. Annual emissions of $\mathrm{N}_{2} \mathrm{O}$ measured during 2 years were $8-28 \mathrm{~kg} \mathrm{~N}^{-1}$. The most probable reasons for high $\mathrm{N}_{2} \mathrm{O}$ emission rates in AS soils are concomitant large mineral $\mathrm{N}$ pools with fluctuating redox conditions and low $\mathrm{pH}$ in the oxidized subsoil, all favoring formation of $\mathrm{N}_{2} \mathrm{O}$ in nitrification and denitrification. Although the groundwater level was higher in $\mathrm{CD}$ and $\mathrm{CDI}$ than in conventional drainage, $\mathrm{N}$ load and crop offtake did not differ between the drainage methods, but there were differences in emissions. Nitrogen flows to the atmosphere and drainage water were clearly larger than those in non-AS mineral soils indicating that AS soils are potential hotspots of environmental impacts.

Keywords Acid sulfate soil · Controlled drainage $\cdot$ Subirrigation $\cdot \mathrm{N}$ leaching $\cdot$ Nitrous oxide emissions

\section{Introduction}

At least $10 \%$ of Finnish agricultural land is located on acid sulfate (AS) soils (Palko 1994) which are known for soil acidification and associated severe environmental hazards in ecosystems of recipient waters (Dent and Pons 1995). In coastal areas of the Baltic Sea, hazards arise from oxidation of sulfides accumulated in the parent material, which in most cases is sea sediment rich in carbon (C) from cyanobacterial blooms (Bianchi et al. 2000). Abundance of dead organic material in these 
sediments served as a source of energy for sulfatereducing bacteria, which converted sulfate in sea water to sulfide that reacted with metal ions to produce metal sulfides such as pyrite $\left(\mathrm{FeS}_{2}\right)$ (Rickard and Luther 2007) or metastable iron sulfides (e.g., Sohlenius and Öborn 2004; Boman et al. 2008). These sulfidic layers are commonly several meters deep and the $\mathrm{C}$ and sulfur (S) stocks are thus much more abundant than in other mineral soils (Öborn 1989; Boman et al. 2008). Owing to postglacial land uplift, AS soils of Finland are concentrated to the coast of the Baltic Sea and are accessible for agricultural use. Artificial drainage is a prerequisite for cultivation, but in AS soils it creates horizons with very low $\mathrm{pH}(<4)$ because newly introduced aerobic conditions trigger oxidation of sulfides and production of sulfuric acid in the subsoil horizons that were waterlogged before drainage.

Large stocks of mineral nitrogen (Nmin) have been found in waterlogged AS subsoil (Cg horizon), mostly in the form of ammonium (Paasonen-Kivekäs and YliHalla 2005; Šimek et al. 2011), which are associated with slow mineralization of the large organic matter stock. Waterlogged conditions are not favorable for the oxidation of ammonium to nitrate in the $\mathrm{Cg}$ horizon, while in the oxidized $\mathrm{Bg}$ horizon nitrification is likely to be prevented by severe acidity and aluminum toxicity. Instead of in situ formation, nitrate may also originate from fertilizers or soil organic matter by mineralization and nitrification in the plough layer and subsequent leaching down to the $\mathrm{Bg}$ and $\mathrm{Cg}$ horizons. It has been postulated that nitrate/nitrite can be chemically reduced to ammonium in the presence of sulfides (Brunet and Garcia-Gil 1996). The fate of the large Nmin stock in AS subsoil is largely unknown, but water quality monitoring in Finland in 1965-2010 (Rekolainen 1989; Tattari et al. 2017) suggested that presence of AS soils in a catchment increases the $\mathrm{N}$ load to watercourses.

As sulfur can interfere with $\mathrm{C}$ and $\mathrm{N}$ cycles, the biogeochemistry of AS soils can be affected, with implications for the greenhouse gas balance. In particular, high nitrous oxide $\left(\mathrm{N}_{2} \mathrm{O}\right)$ emissions have been reported from AS soils (Denmead et al. 2010; Macdonald et al. 2011; Petersen et al. 2012). In anoxic conditions, production of $\mathrm{N}_{2}$ and $\mathrm{N}_{2} \mathrm{O}$ may be caused by nitrate reduction coupled with oxidation of iron sulfides or ferrous iron $\left(\mathrm{Fe}^{2+}\right)$ (Postma et al. 1991; Schippers and Jørgensen 2002; Vaclavkova et al. 2014; Virtanen 2015). Low pH may further increase the proportion of $\mathrm{N}_{2} \mathrm{O}$ in the end products of denitrification by inhibiting $\mathrm{N}_{2} \mathrm{O}$ reductase (Thomsen et al. 1994).
Acidification of waters caused by AS soils can be partly alleviated by keeping the sulfidic horizon waterlogged and thus preventing oxidation of sulfides. For this purpose, controlled drainage (CD) (e.g., Palko 1994; Österholm et al. 2015), and sub-irrigation associated with controlled drainage (CDI) (Österholm et al. 2015) have been tested in situ in AS fields resulting in at least slightly lower acidity in discharge water (Åström et al. 2007; Johnston et al. 2014; Virtanen et al. 2016). In non-AS fields, controlled drainage can decrease nitrate loading by $18-75 \%$ (Ritzema and Stuyt 2015), mainly due to higher evapotranspiration resulting in lower drain discharge but also to more efficient use of nutrients (Wesström et al. 2014; Ritzema and Stuyt 2015). In a field and simulation study in Canada, Jiang et al. (2019) observed that controlled drainage reduced $\mathrm{CO}_{2}$ emissions but increased $\mathrm{N}_{2} \mathrm{O}$ emissions due to higher denitrification in a non-acid soil.

Acidification of soil and watercourses caused by cultivation of AS soils has been widely studied but other environmental consequences are less well researched. In order to assess $\mathrm{N}$ flows in AS soils, we quantified the $\mathrm{N}$ stocks and monitored $\mathrm{N}$ uptake by crop yield, leaching of $\mathrm{N}$, and $\mathrm{N}_{2} \mathrm{O}$ emissions in three adjacent fields on an AS soil on the western coast of Finland. We also studied how different subsurface pipe drainage practices affected $\mathrm{N}$ loading to watercourses or emissions to the atmosphere. Owing to the large N stock in AS soils, it was hypothesized that (1) $\mathrm{N}$ loading and (2) emissions from AS soils are large, and that controlled drainage (CD) and especially sub-irrigation (CDI) lead to (3) less leaching of $\mathrm{N}$ and (4) lower $\mathrm{N}_{2} \mathrm{O}$ emissions due to longer anoxic periods in subsoil and lower mineralization of the $\mathrm{N}$ stock.

\section{Materials and methods}

Experimental field and its management

The experiment was established in 2010 on three adjacent fields (total area $18.5 \mathrm{ha}$ ) in a polder area of Söderfjärden $\left(63^{\circ} 0.1896^{\prime} \mathrm{N}, 21^{\circ} 35.4747^{\prime} \mathrm{E}\right)$ near Vaasa in Western Finland in 2010. The polder was reclaimed for agriculture in the 1920s and the parent material consists of Holocene sulfide-bearing marine sediments. The area and the experimental setup and treatments (Fig. 1) are described in detail by Österholm et al. (2015). Groundwater (GW) level, concentration of 
$\mathrm{N}$ in drainage water, and grain yield were monitored in 2010-2017. Emissions of $\mathrm{N}_{2} \mathrm{O}$ were measured periodically in 2010-2014 and mechanisms leading to $\mathrm{N}_{2} \mathrm{O}$ emissions were studied in laboratory experiments.

The soil has a silt loam Ap horizon $(0-28 \mathrm{~cm})$ while the subsoil consists of silty clay loam. A gleyic color pattern with a strong structure and continuous iron hydroxide coatings is visible throughout the $\mathrm{Bg}(28-120$ $\mathrm{cm})$ and $\mathrm{BCg}(120-150 \mathrm{~cm})$ horizons. The $\mathrm{Cg}$ horizon below $150 \mathrm{~cm}$ has a massive structure, with no rust mottles, and contains black sulfidic material inherited from the parent sediment. The soil is classified as Sulfic Cryaquepts (Soil Survey Staff 2014) and Thionic Gleysols (drainic, humic, loamic/siltic) (IUSS Working Group WRB 2015).

The experimental fields were around $80-100 \mathrm{~m}$ wide and 710-740 $\mathrm{m}$ long. The surface of the lower part of each field, closest to the main drain, is $1.9 \mathrm{~m}$ above the mean sea level (MSL) and the edge farthest from the main drain (upper part) is $2.9 \mathrm{~m}$ above MSL, the slope being $<0.2 \%$ (Fig. 1). The fields had existing subsurface drainage pipes at $1.1 \mathrm{~m}$ with control wells (Fig. 1). The following experimental water management systems were practiced in the individual fields: (1) conventional subsurface drainage (CONV), (2) controlled subsurface drainage (CD), and (3) controlled subsurface drainage with additional pumping of water into the control wells during dry periods (sub-irrigation, CDI). In order to have similar drain spacing (26-28 m) in each experimental field, before sowing in May 2010, supplementary drains were installed in the CONV field, where the existing drainage system originating from the 1950s had a wider drain spacing. Although 2010 was meant to be a calibration period by keeping the wells open (i.e., applying CONV) in each field during the growing season, due to drought, additional water was pumped into a closed control well in July by the farmer managing the CDI field. The amount of sub-irrigation in 2011-2014 was $31 \mathrm{~mm}, 50 \mathrm{~mm}, 12 \mathrm{~mm}$, and $28 \mathrm{~mm}$, respectively, with $22 \mathrm{~mm}$ in 2016. No sub-irrigation was applied in 2015 and 2017 because water was not available, and thus the CD treatment was applied to the CDI field in those years.

In order to prevent bypass flow, all three test fields were hydrologically isolated from each other and from the main drain using vertical plastic sheets from 0.3down to $1.8-\mathrm{m}$ depth, extending into the impermeable massive parent sediment. Continuous and real-time measuring devices were installed in each field after crop harvest in September 2010. Perforated groundwater (GW) pipes were installed in each field to 2.5-m depth; one for a GW logger (pressure sensor, EHP GWL-600, EHP-Tekniikka Ltd., Oulu, Finland) and three other pipes for manual GW measurements in the lower, middle, and upper part of the field. The manual measurements were made by tape measure. In the lowest section of the fields, the manually and continuously measured groundwater pipes were only about $1 \mathrm{~m}$ apart. The mean difference between simultaneous continuous and manual GW measurements was $20 \pm 18 \mathrm{~cm}$.

During the growing season, precipitation data were collected with a simple rain gauge near the experimental field by a local farmer or with a RainWise MK III weather station (EHP-Tekniikka Ltd., Oulu, Finland) in the field. Precipitation data from the weather station was not always available due to problems caused by gull excrement. Air temperature was measured with a Vaisala HMP45 sensor in the field. Annual precipitation and air temperature data throughout the year were extracted from the databases at the Finnish Meteorological Institute (Table 1).

The area was farmed in a coordinated manner by the three local farmers who own the fields. Spring barley was grown in 2010, 2012, 2014, 2016, and 2017 and spring wheat in 2011, 2013, and 2015. The fields were sown in May, with simultaneous application of NPK mineral fertilizer at the rate of 90 and $110-125 \mathrm{~kg} \mathrm{~N}$ $\mathrm{ha}^{-1}$ for barley and wheat, respectively. Crop yield was quantified using an experimental harvester (width 1.5 $\mathrm{m}$ ), harvesting 15-m-long representative sections of the lower, middle, and upper sections of each field. The grain samples were analyzed for moisture and $\mathrm{N}$ concentration. Straw yield was measured in 2010, 2012, and 2013 and analyzed for $\mathrm{N}$ in 2010 . The straw was incorporated into the soil by ploughing.

Sampling of soil and water

Soil profiles at the lower and upper section of each field were sampled in autumn 2009 with an auger at vertical depth intervals of $10 \mathrm{~cm}$ down to $2.0 \mathrm{~m}$ and the $\mathrm{pH}(1: 1)$ in deionized water was measured in the field (Österholm and Åström 2002). Soil samples were taken at intervals of $20 \mathrm{~cm}$ down to $2.0 \mathrm{~m}$ from the lower section of each field in May 2012 and analyzed for total C and N by dry combustion (LECO, St. Joseph, MI, USA). Bulk density (BD) of the two uppermost sections, needed for conversion of $\mathrm{C}$ and $\mathrm{N}$ concentrations to kilograms per hectare, 


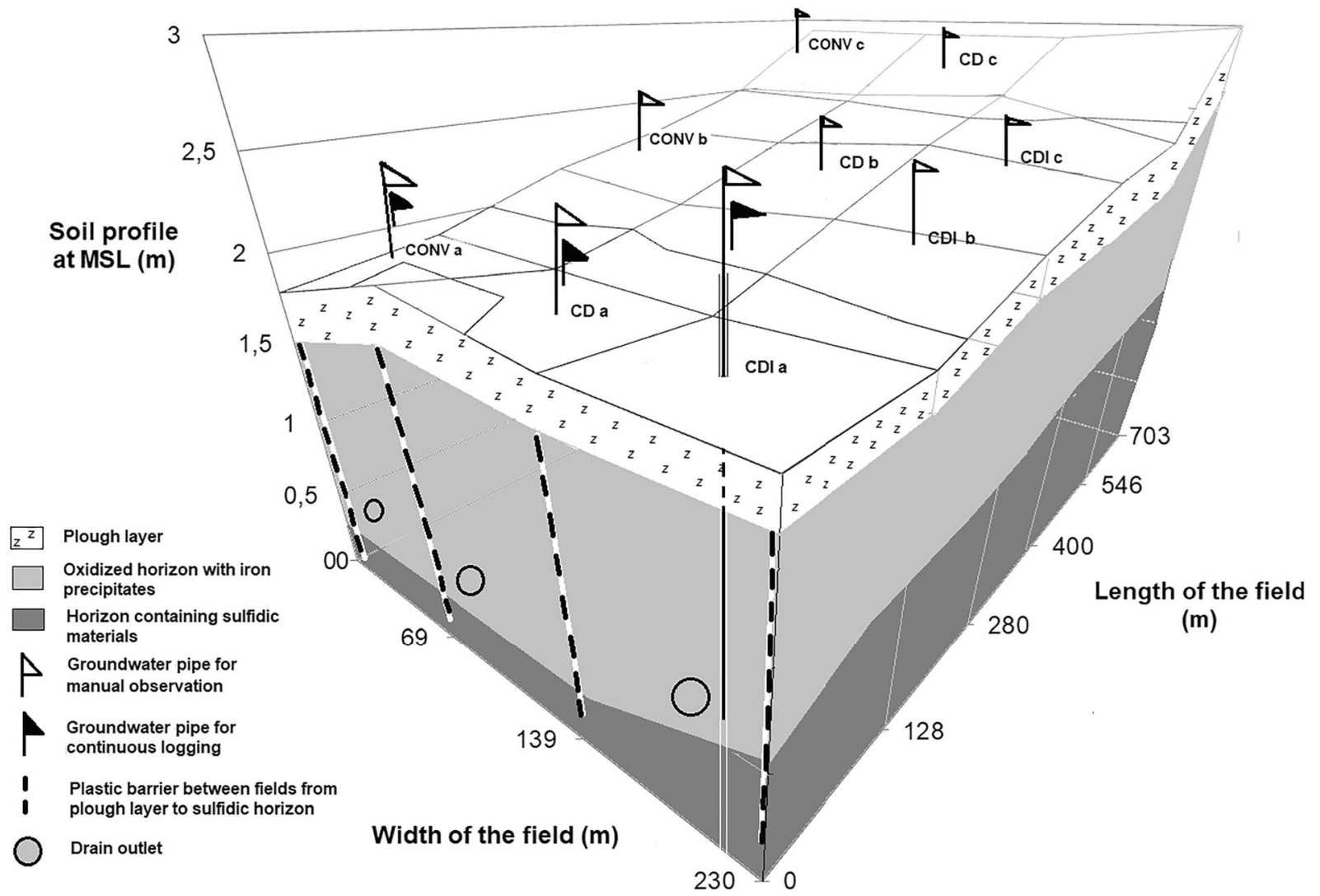

Fig. 1 Layout of the experimental area showing the locations of the subsurface drainage pipes, groundwater observation pipes, structures preventing water flow between fields, and soil horizons in the experimental area relative to mean sea level (MSL). The fields have three different water management practices: CONV = conventional subsurface drainage, $\mathrm{CD}=$ controlled drainage, $\mathrm{CDI}$ $=$ controlled drainage with sub-irrigation was determined using $0.04-\mathrm{dm}^{3}$ cylinders. Owing to a rather uniform organic $\mathrm{C}$ content, it was assumed that deeper layers had the same BD as at $20-40 \mathrm{~cm}$. The plough layer (Ap horizon) and the upper part of the $\mathrm{Bg}$ horizon $(25-40 \mathrm{~cm})$ in the lower, middle, and upper section of each field were sampled in May 2010-2013 for Nmin. Additionally, the soil was sampled for Nmin analysis at depths of 100-120 cm (lower part of the $\mathrm{Bg}$ horizon), 130-150 cm (BCg horizon), and 170-190 cm (Cg horizon) in September 2013. The soil samples were stored frozen until Nmin was extracted with $2 \mathrm{M} \mathrm{KCl}$ (Esala 1995). The concentrations of ammonium-N $\left(\mathrm{NH}_{4}{ }^{+}-\mathrm{N}\right)$ and nitrate- $\mathrm{N}\left(\mathrm{NO}_{3}{ }^{-}-\mathrm{N}\right)$ were determined colorimetrically with an autoanalyzer (Lachat QuickChem AE, Hach, Loveland, CO, USA, or Skalar San++ System, Skalar Analytical B.V., Breda, the Netherlands).
An EHP-UltraSonic Flow monitoring system (EHPTekniikka Ltd., Oulu, Finland) was installed in order to monitor the water flow $\left(\mathrm{dm}^{3} \mathrm{~s}^{-1}\right)$ online, continuously and in real time in the outlet pipe of each field. The system was a combination of an EHP DL-6 data-logger with an amkf12 gsm/gprs-modem, Fluxus 5107 ultrasonic device, 2-m EHP pipe, accumulators, and solar panels. The data logger transmitted the raw data detected by the sensors to an online server (http://www.ehpdata.com). Daily data were manually corrected by removing negative and suspiciously high values, and faulty values measured at low battery current. Upon conversion from cubic decimeter per second to cubic decimeter per second per hectare and millimeter per year, it was assumed that the drainage basin was only the area bordered by the plastic sheet for each field (5.66 ha in CONV, 5.97 ha in CD, and 6.75 ha in CDI). 
Table 1 Meteorological data for the Söderfjärden experimental area. All values were extracted from the Finnish Meteorological Institute database except precipitation during the growing season in seven years, which was measured directly in the field. Average precipitation and temperature at Vaasa airport, $10 \mathrm{~km}$ from the experimental field, in 1981-2010 was $552 \mathrm{~mm}$ and $4.2{ }^{\circ} \mathrm{C}$, respectively

\begin{tabular}{lllllll}
\hline Year & $\begin{array}{l}\text { Mean air } \\
\text { temperature }(3),{ }^{\circ} \mathrm{C}\end{array}$ & $\begin{array}{l}\text { Annual precipitation } \\
(3), \mathrm{mm}\end{array}$ & $\begin{array}{l}\text { Precipitation during } \\
\text { growing period (4), mm }\end{array}$ & $\begin{array}{l}\text { Growing degree } \\
\text { days }(1),{ }^{\circ} \mathrm{C}\end{array}$ & $\begin{array}{l}\text { Growing } \\
\text { season }\end{array}$ & $\begin{array}{l}\text { Length of growing } \\
\text { period, days }\end{array}$ \\
\hline $2010(5)$ & - & 540 & $159(2)$ & - & $8.5 .-11.10$. & 156 \\
2011 & 5.9 & 617 & $304(2)$ & 1446 & $16.4 .-18.11$. & 217 \\
2012 & 4.3 & 687 & $199(1)$ & 1171 & $23.4 .-19.10$. & 180 \\
2013 & 5.9 & 556 & $260(2)$ & 1387 & $2.5 .-15.10$. & 167 \\
2014 & 6.0 & 547 & $193(1)$ & 1321 & $17.4 .-13.10$. & 180 \\
2015 & 6.4 & 738 & $399(2)$ & 1146 & $19.4 .-11.11$. & 207 \\
2016 & 5.2 & 665 & $455(2)$ & 1272 & $28.4 .-4.10$. & 160 \\
2017 & 5.2 & 636 & $173(1)$ & 1040 & $16.5 .-18.10$. & 156 \\
Mean & 5.7 & 623 & 268 & 1255 & & 181
\end{tabular}

(1) Measured in the field or (2) next to the field. (3) Measured at Mustasaari, Riimala, $14 \mathrm{~km}$ away from the field. (4) Precipitation between sowing and harvesting of the crop. (5) Incomplete experimental year

Representative drainage water samples were collected from November 2010 until December 2017, under thawless moderate to high flow conditions $\left(>0.1 \mathrm{dm}^{3}\right.$ $\mathrm{s}^{-1}$ ), in spring (April-May; $n=16$ ) and autumn (October-December; $n=23$ ). These samples were taken from the lowest well of each field. In 2010 and 2012, a total of 7-9 samples per year were taken, while in 2011, and 2013-2017, the annual number was 11-13. The water samples were analyzed for electrical conductivity (EC; SFS-EN 27888:1994), Ntot, $\mathrm{NH}_{4}{ }^{+}-\mathrm{N}, \mathrm{NO}_{3}{ }^{-}-\mathrm{N}$, and nitrite- $\mathrm{N}\left(\mathrm{NO}_{2}{ }^{-}-\mathrm{N}\right)$. A colorimetric flow injection analysis (FIA) method was used for the determination of $\mathrm{NH}_{4}{ }^{+}-\mathrm{N}$, $\mathrm{NO}_{3}{ }^{-}-\mathrm{N}$, and $\mathrm{NO}_{2}{ }^{-} \mathrm{N}$ according to Finnish standard methods (SFS-EN ISO 11732:2005, SFS-EN ISO 13395:1997). For determination of Ntot, the water samples were digested with $\mathrm{K}_{2} \mathrm{~S}_{2} \mathrm{O}_{8}$ (ISO 11905-1:1997).

The concentration of $\mathrm{NO}_{x}^{-}-\mathrm{N}$ ( sum of $\mathrm{NO}_{3}{ }^{-}-\mathrm{N}$ and $\mathrm{NO}_{2}{ }^{-}-\mathrm{N}$ ) was continuously monitored (Hach-Langen Nitratax sensor) in the lowest control well of CDI from April 2012 until the end of November 2014. In order to discover which soil horizons are the main sources for $\mathrm{N}$ leaching, we calculated the daily $\mathrm{NO}_{x}{ }^{-}-\mathrm{N}$ and $\mathrm{GW}$ values and plotted $\mathrm{NO}_{x}^{-}-\mathrm{N}$ concentration and GW level in the soil profile against the measurement date. From the daily locations of GW in every $20-\mathrm{cm}$ range of a depth in the soil profile, the median of $\mathrm{NO}_{x}^{-}-\mathrm{N}$ was calculated for spring, summer, and autumn. The other continuously monitored parameters (GW, EC, discharge) were compiled in a similar manner. Negative daily discharge and $\mathrm{NO}_{x}{ }^{-}-\mathrm{N}$ concentrations $<1 \mathrm{mg} \mathrm{L}^{-1}$ were filtered out to exclude the effect of stagnant water in the control well. During floods, the outlets of the drain pipes were below the water surface in the nearby ditch, and ditch water could flow back through the pipes into the field. When the floodwaters receded, water flow from the field through the drain pipes resumed. Surface runoff caused by floodwaters was not measured.

The $\mathrm{N}$ load for each field was calculated from grab sampling and continuous monitoring data using the following equation:

Annual N load $\left(\mathrm{kg} \mathrm{ha}^{-1}\right)=C_{w} \times Q$

where $C_{w}$ is the runoff weighted average $\mathrm{N}$ concentration $\left(\mathrm{mg} \mathrm{L}^{-1}\right)$ in grab samples taken from the well in the lowest section of each field, and $Q$ is the cumulative discharge of measured continuous runoff $\left(\mathrm{L} \mathrm{ha}^{-1}\right)$.

Measurement of $\mathrm{N}_{2} \mathrm{O}$ fluxes and denitrifying enzyme activity

The $\mathrm{N}_{2} \mathrm{O}$ flux was measured with a closed chamber technique in the field experiment during three periods, Oct 2010-Sept 2011, May 2012-May 2013, and JuneAug 2014. Due to limited resources, the measurements were conducted at low frequency and varying intervals; nine times in 2010-2011, 14 times in 2012-2013, and eight times in 2014. Five replicate steel collars were installed in the lower section of each field (Fig. 1), and removed only when necessary for farming operations. A 
water seal between the edge of the collar and the chamber ensured gas tightness of the chamber (Kanerva et al. 2007). Chamber measurements were carried out using closed aluminum chambers from which four samples were taken during $45 \mathrm{~min}$. Gas samples $(20 \mathrm{~mL})$ were taken with BD Plastipak polypropylene syringes (Becton, Dickinson and Company, Franklin Lakes, NJ, USA) and stored in pre-evacuated 12-mL Exetainer glass vials (Labco Ltd., High Wycombe, UK).

The $\mathrm{N}_{2} \mathrm{O}$ concentrations were also measured at depths of 30,50 , and $70 \mathrm{~cm}$ in the soil profile on seven occasions in summer 2012. Sampling lines made from 1-mm PTFE tube were installed in the soil at three replicate locations per plot. A sintered polyethylene filter (pore diameter $100 \mu \mathrm{m}$ ) was placed at the sampling depth and a 5-mL sample was drawn through the filter after discarding the first $5 \mathrm{~mL}$.

The gas samples were analyzed for $\mathrm{N}_{2} \mathrm{O}$ with a gas chromatograph (details in Kanerva et al. 2007). A reference gas mixture (AGA Gas AB, Lidingö, Sweden) of known concentrations of $\mathrm{N}_{2} \mathrm{O}$ was used for the calibration curve. The linear response resulting from analysis of the four gas samples taken during the 45-min enclosure period was used for calculating the emission rate. The volume of gas in the chamber was corrected according to the chamber temperature. The annual rates of gas fluxes were calculated with linear interpolation of the daily flux rates between subsequent sampling days for the periods Oct 27, 2010-Oct 26, 2011 and May 28, 2012-May 27, 2013.

The effect of soil $\mathrm{pH}$ on denitrifying enzyme activity (DEA) was studied in the Ap (0-20 cm) and Bg (80-100 $\mathrm{cm})$ horizons in CONV. Soil for these analyses was taken in June 2014 as 15 pooled subsamples close to the gas measurement frames of each field. The samples were stored at $+4{ }^{\circ} \mathrm{C}$ and sieved $(2 \mathrm{~mm})$ just before use. Five replicate $20 \mathrm{~g}$ soil samples were weighed into 120 -mL incubation flasks and kept in room temperature for an hour. To adjust the desired $\mathrm{pH}$, a 20-mL aliquot of a solution of $\mathrm{H}_{2} \mathrm{SO}_{4}$ or $\mathrm{NaOH}$ was added according to a preliminary test. Next, $5 \mathrm{~mL}$ of a solution containing glucose $\left(100 \mathrm{mg} \mathrm{L}^{-1}\right)$ and $\mathrm{KNO}_{3}\left(500 \mathrm{mg} \mathrm{L}^{-1}\right)$ were added, and the flasks were closed with butyl rubber septa and evacuated using a vacuum pump. To ensure anaerobic conditions, the evacuation and flushing with helium was performed four times. After the last round of evacuating, the flasks were filled with helium again, the overpressure was released through a needle, and acetylene was added to half the replicates to obtain a final concentration of $10 \%$ acetylene in the gas phase. The samples were shaken in a rotary shaker $(180 \mathrm{rpm})$ and 1 -mL gas samples were taken at $1 \mathrm{~min}$ and $60 \mathrm{~min}$ and analyzed as described above.

\section{Statistical analyses}

Parameters monitored at 10- to 30-min intervals were aggregated into daily values by summation (precipitation and discharge) or taking their daily means (GW, EC). Differences in GW between the fields were determined using the Mann-Whitney rank sum test in SigmaPlot 12.3. Differences in Nmin content of the soil at $0-40 \mathrm{~cm}$ between the years were tested with one-way ANOVA. Standard deviation (SD) was calculated for the annual grain yields and $\mathrm{N}$ offtakes in CONV, CD, and CDI, using the results of the three harvested sections of the respective field as replicates. Standard deviation of $\mathrm{N}$ concentrations in water samples was calculated separately for autumn and spring. Statistical analysis of the field greenhouse gas data was performed using the SAS Enterprise Guide software, version 7.1. The effect of drainage treatment on field fluxes of $\mathrm{N}_{2} \mathrm{O}$ was studied using the generalized linear mixed model approach. The estimation technique was restricted maximum likelihood (REML) and the method of estimating degrees of freedom was Kenward-Roger 2. The values of $\mathrm{N}_{2} \mathrm{O}$ were log-transformed to normalize their distribution. Differences in DEA were tested for significance using the independent sample $T$ test in IBM SPSS version 22.

\section{Results}

Carbon and nitrogen stocks and soil $\mathrm{pH}$

It was found that the natively low $\mathrm{pH}$ of the Ap horizon at the site had been elevated over time by heavy liming, whereas the oxidized $\mathrm{Bg}$ horizon had a $\mathrm{pH}$ between 3.9 and 5.0 (Fig. 2). The $\mathrm{pH}$ of the $\mathrm{BCg}$ horizon was higher than that in the horizon above, and the $\mathrm{pH}$ reached neutrality in the reduced parent sediment (Cg horizon). The concentrations of $\mathrm{C}$ and $\mathrm{N}$ in the soil profile were rather uniform, being marginally higher in the subsoil at 120-160-cm depth (Fig. 3). Total stocks of C and N were 162 and $19.5 \mathrm{tha}^{-1}$, respectively, in the uppermost 100-cm layer of soil, and 194 and $26.6 \mathrm{tha}^{-1}$, respectively, at 100-200-cm depth. 
Fig. 2 Genetic horizons and soil $\mathrm{pH}$ in the upper and lower sections of each field, measured in autumn 2009. The error bars indicate standard deviation calculated for the three fields

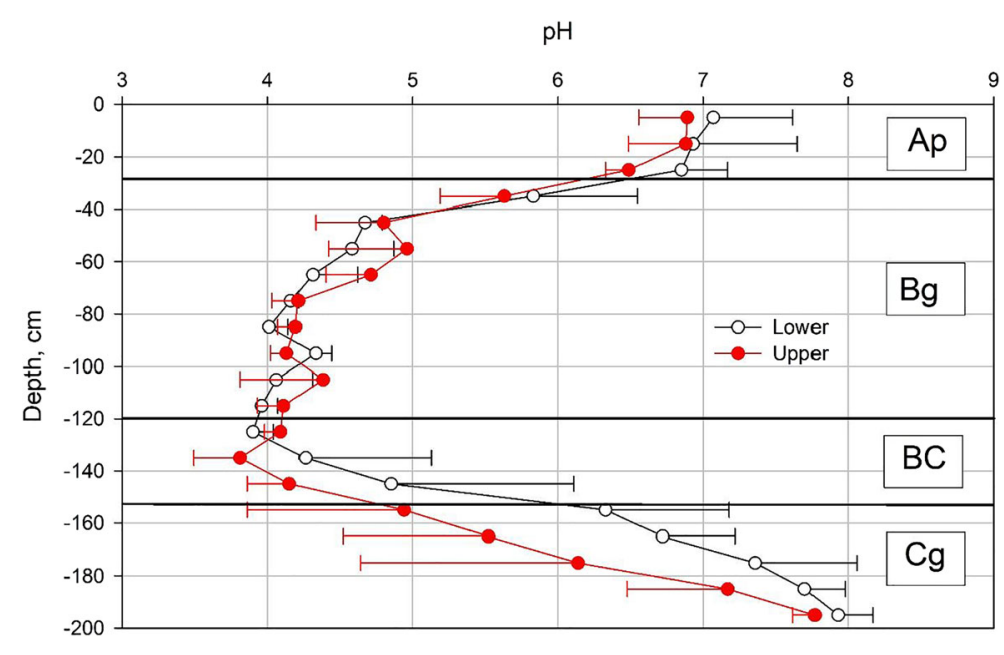

Mineral nitrogen in soil

There was a decreasing trend in Nmin during the 4-year measurement period. In spring of the last 2 years (20122013), Nmin amounted to only about half the value measured earlier (2010-2011) (Table 2). The difference was attributable almost solely to $\mathrm{NO}_{3}{ }^{-}-\mathrm{N}$ while the amount of $\mathrm{NH}_{4}{ }^{+}-\mathrm{N}$ was nearly constant every spring. There was little difference in Nmin concentrations between the two sampled layers $(0-25 \mathrm{~cm}, 25-40 \mathrm{~cm})$ and therefore their results are not shown separately. The $\mathrm{NO}_{3}{ }^{-}-\mathrm{N}$ fraction amounted to $54-78 \%$ of the entire Nmin, with the percentage being higher in years with higher amounts of Nmin. There were no significant differences in Nmin at $0-40 \mathrm{~cm}$ between the fields (i.e., drainage methods) in any of the 4 years for which Nmin was measured. When the horizons below $40 \mathrm{~cm}$ were also analyzed for Nmin in 2013, it emerged that the largest Nmin stock was deeper in the soil than crop roots commonly reach. At $100-120 \mathrm{~cm}$ in the oxidized subsoil $(\mathrm{Bg}), \mathrm{Nmin}$ amounted to $28 \mathrm{~kg} \mathrm{ha}^{-1}$, with $\mathrm{NO}_{3}{ }^{-}-\mathrm{N}$ comprising $86 \%$, while at $130-150 \mathrm{~cm}(\mathrm{BCg}) \mathrm{Nmin}$ was at a similar level $\left(23 \mathrm{~kg} \mathrm{ha}^{-1}\right)$ but at this depth $\mathrm{NH}_{4}{ }^{+}-\mathrm{N}$ started to dominate the pool, comprising $79 \%$. In the reduced subsoil at $170-190 \mathrm{~cm}(\mathrm{Cg})$, Nmin increased to $200 \mathrm{~kg} \mathrm{ha}^{-1}$, all in the form of $\mathrm{NH}_{4}{ }^{+}-\mathrm{N}$.

Water management and groundwater level

The GW level varied seasonally rising up to the soil surface after snow melt in spring and due to frequent rainfall events in autumn (Fig. 4). Low GW was typical in summer but the lowest values $(2.4 \mathrm{~m}$ below soil surface) occurred in late autumn. During the seven experimental years, a general falling trend in GW was observed, especially in CONV. The farmers dredged the main drain in autumn 2014 and 2017, which was reflected as lower GW thereafter (Fig. 4). The highest

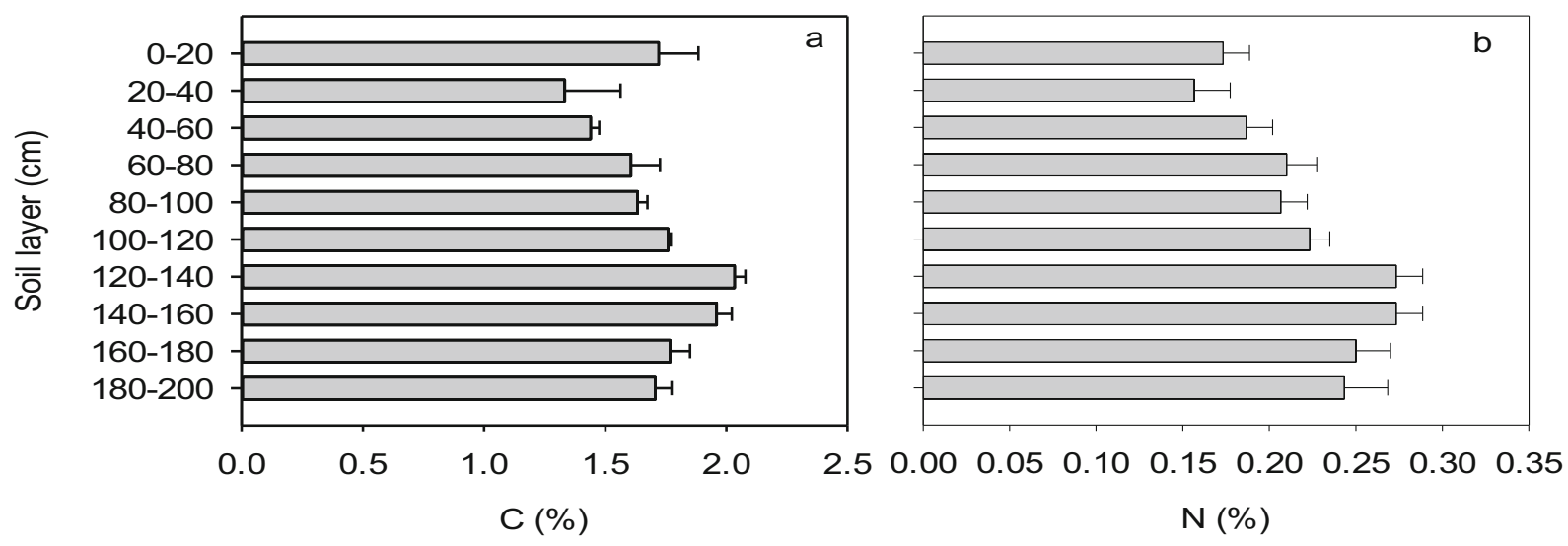

Fig. 3 Content of a total carbon (C) and $\mathbf{b}$ total nitrogen $(\mathrm{N})$ in the soil profile (mean and standard deviation of the results of all three fields) 
Table 2 Mineral nitrogen (N) content in the 0-40-cm soil layer in May 2010-2013. Each row was tested separately. Means marked with different letters are significantly different $(p=0.05)$

\begin{tabular}{|c|c|c|c|c|c|}
\hline & 2010 & 2011 & 2012 & 2013 & $F$ value \\
\hline $\mathrm{NO}_{3}{ }^{-}-\mathrm{N}, \mathrm{kg} \mathrm{ha}^{-1}$ & $30.3^{\mathrm{a}}$ & $33.8^{\mathrm{a}}$ & $15.4^{\mathrm{b}}$ & $14.5^{\mathrm{b}}$ & $28.637 * * *, p<0.001$ \\
\hline $\mathrm{NH}_{4}^{+}-\mathrm{N}, \mathrm{kg} \mathrm{ha}^{-1}$ & $12.9^{\mathrm{a}}$ & $8.4^{\mathrm{a}}$ & $7.6^{\mathrm{a}}$ & $10.8^{\mathrm{a}}$ & $2.401^{\text {n.s. }}, p=0.09$ \\
\hline Nmin, $\mathrm{kg} \mathrm{ha}^{-1}$ & $43.2^{\mathrm{a}}$ & $42.2^{\mathrm{a}}$ & $23.0^{\mathrm{b}}$ & $25.3^{\mathrm{b}}$ & $15.856^{* * *}, p<0.001$ \\
\hline
\end{tabular}

GW was observed in CDI where the sub-irrigation helped to maintain the GW level. The GW was higher in CD than in CONV, but lower than in CDI, because damming by the regulation wells alone cannot raise $\mathrm{GW}$ in the field without replenishment of water by rainfall. Consequently, GW dropped to the critical Cg horizon for fewer days in CDI (137 days) and CD (259 days) than in CONV (631 days) during the whole study period (Nov. 2011-Dec. 2017). In 2015 and 2017, the main ditch dried up and CDI functioned like CD. However, in these years, the GW in CDI was higher than that in $\mathrm{CD}$ by an average of $18 \mathrm{~cm}$. The highest annual mean difference between CDI and CONV was $66 \mathrm{~cm}( \pm 19$ $\mathrm{cm})$ and between CD and CONV $29 \mathrm{~cm}( \pm 16 \mathrm{~cm})$ in 2012. The most acidic part of the Bg horizon (80-120 $\mathrm{cm})$ and the entire BCg horizon $(120-150 \mathrm{~cm})$ were below GW and consequently saturated for 1315 days in CDI, 1135 days in CD, and 402 days in CONV. The median GW level was $92 \mathrm{~cm}, 100 \mathrm{~cm}$, and $126 \mathrm{~cm}$ below the soil surface in $\mathrm{CDI}, \mathrm{CD}$, and CONV, respectively. All treatments differed significantly from each other $(p<0.001)$.

Yields and offtake of nitrogen

There were no marked differences in grain yield between the three water management practices, with the average yields (15\% moisture) being 5900, 5880, and $5990 \mathrm{~kg} \mathrm{ha}^{-1}$ in CONV, CD, and CDI, respectively, while the annual differences were much more pronounced (Fig. 5a). Straw yield, measured in 20102013 , averaged at $2680-3100 \mathrm{~kg} \mathrm{ha}^{-1}$ in different years and constituted $39 \%$ of aboveground dry matter. Offtake of $\mathrm{N}$ in harvested grain (Fig. 5b) averaged $92 \mathrm{~kg} \mathrm{ha}^{-1}$ and corresponded to $92 \%$ of the amount applied in fertilization. Straw yield, analyzed for N only in 2010, contained $30.8 \mathrm{~kg} \mathrm{~N}^{-1}$ and represented $29 \%$ of total $\mathrm{N}$ uptake by the crop.
Nitrogen in water samples

In grab samples collected in spring and autumn 20112017, the median of $\mathrm{NO}_{3}{ }^{-}-\mathrm{N}$ concentration was 15.5 (range 0.32-31), 17.0 (2.0-29), and 13 (2.1-31) $\mathrm{mg} \mathrm{L}^{-1}$ in CDI, CD, and CONV, respectively. The $\mathrm{NO}_{x}^{-}-\mathrm{N}$ in drainage water was extremely high (up to $26 \mathrm{mg} \mathrm{L}^{-1}$ ) during high discharge in spring and autumn runoff, but decreased during the growing season (Fig. 6). In June, there was a sharp decrease in $\mathrm{NO}_{x}^{-}-\mathrm{N}$ concentration immediately after pumping of ditch water with low $\mathrm{NO}_{x}^{-}-\mathrm{N}$ concentration $\left(<5 \mathrm{mg} \mathrm{L}^{-1}\right)$ into the control wells. During heavy floods caused by snow melt in spring, $\mathrm{NO}_{x}^{-}-\mathrm{N}$ was also lower, since melt water and flood water diluted the concentration in the field. Continuously measured $\mathrm{NO}_{x}^{-}-\mathrm{N}$ concentrations followed those of $\mathrm{NO}_{3}{ }^{-}-\mathrm{N}$ in grab samples (Fig. 6), the mean difference being $1 \mathrm{mg} \mathrm{L}^{-1}\left(\mathrm{SD}_{2} \mathrm{mg} \mathrm{L}^{-1}\right)$.

The concentration of $\mathrm{NO}_{x}^{-}-\mathrm{N}$ increased when GW rose, with the exception of two seasons when a slight decrease took place (Fig. 7). The highest $\mathrm{NO}_{x}{ }^{-}-\mathrm{N}$ concentration (median $24 \mathrm{mg} \mathrm{L}^{-1}$ ) was found in autumns when the field flooded and GW was within 0-20 cm from the soil surface, but also when GW was at 80-120cm depth (median $21 \mathrm{mg} \mathrm{L}^{-1}$ ). The EC of discharge water increased with decreasing GW, and obviously drain discharge increased when GW rose and ceased when GW dropped below the drainage depth.

The procedure for tracing the origin of leached $\mathrm{NO}_{x}^{-}-\mathrm{N}$ was validated using data on continuously measured EC in discharge water and GW depth. EC was selected for the test because in active AS soils there is a very strong correlation between $\mathrm{EC}$ and $\mathrm{SO}_{4}{ }^{2-}$ in discharge water (e.g., Åström and Björklund 1997; Toivonen and Österholm 2011), an observation made also in our experimental area (Virtanen et al. 2016). In our study fields, oxidation of sulfidic material, producing $\mathrm{SO}_{4}{ }^{2-}$ and elevated $\mathrm{EC}$ in the discharge water, occurred mostly in the $\mathrm{BCg}$ horizon at $120-150 \mathrm{~cm}$ 

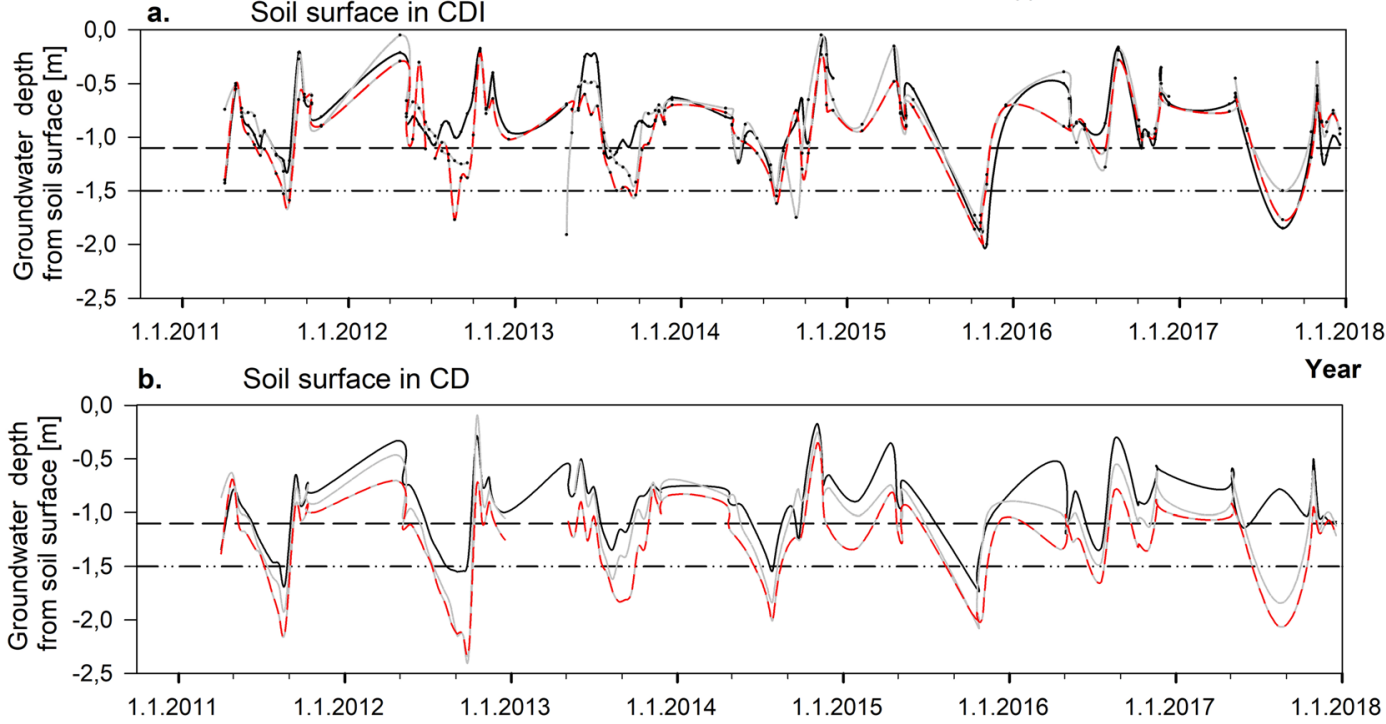

c. Soil surface in CONV
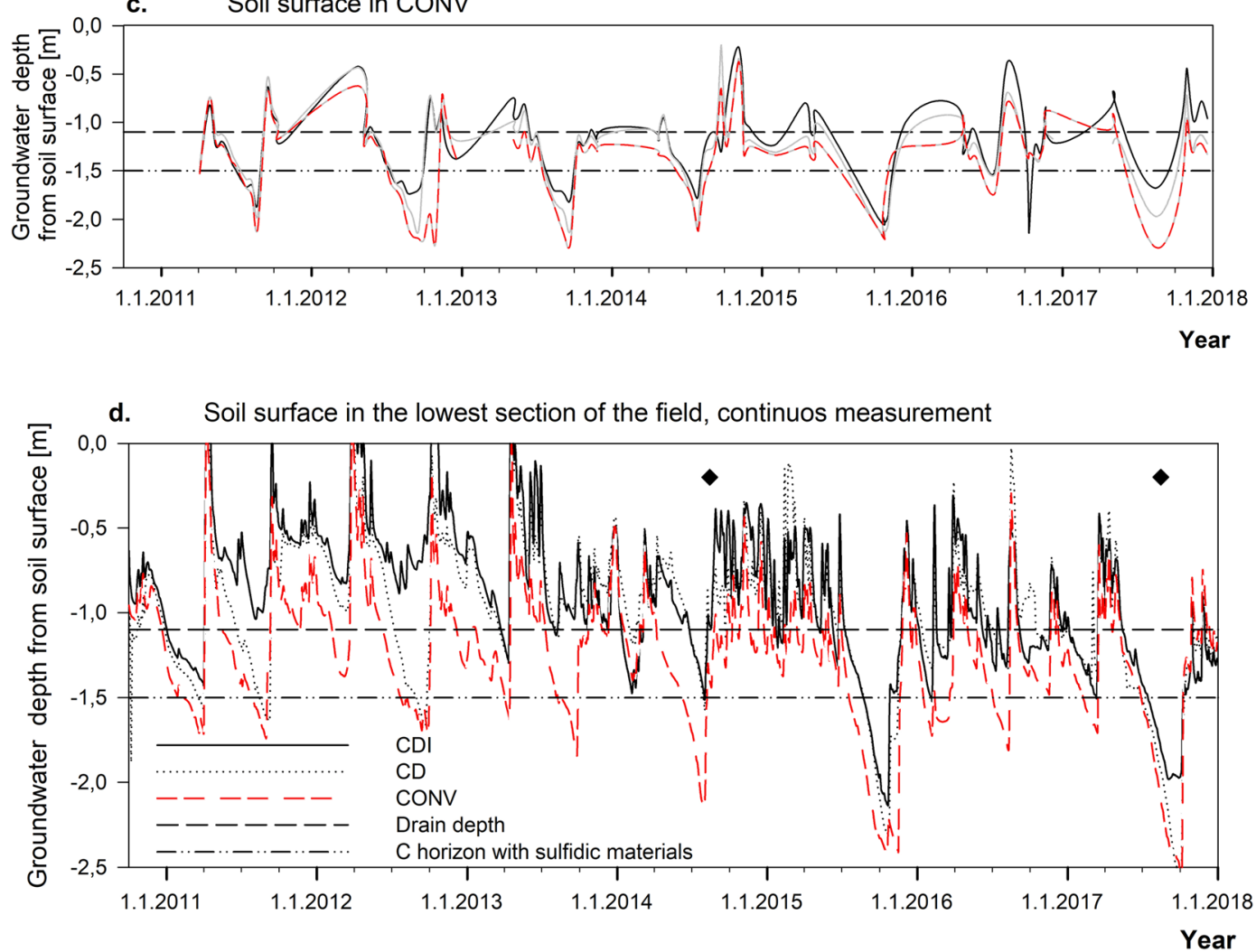

Fig. 4 Results of manual groundwater level measurements in the lowest, middle, and upper section of the fields in the a subirrigated (CDI), b controlled drainage (CD), and $\mathbf{c}$ conventional subsurface pipe drainage (CONV) treatments in 2011-2017. d
Results of continuous groundwater level measurements in the lowest part of the experimental area in 2011-2017. The diamond symbols indicate date of dredging of the main drain 
Fig. 5 a Grain yield in the different water management treatments and $\mathbf{b}$ nitrogen $(\mathrm{N})$ offtake in the harvested grain and amount of $\mathrm{N}$ applied with fertilizer. In 2010, conventional drainage $(\mathrm{CONV})$ was applied also in the controlled drainage treatment (CD). In 2015 and 2017, the controlled drainage with subirrigation (CDI) treatment was identical to $\mathrm{CD}$, because no subirrigation was applied. The error bars indicate standard deviation calculated from the results for the lower, middle, and upper section of each field a)

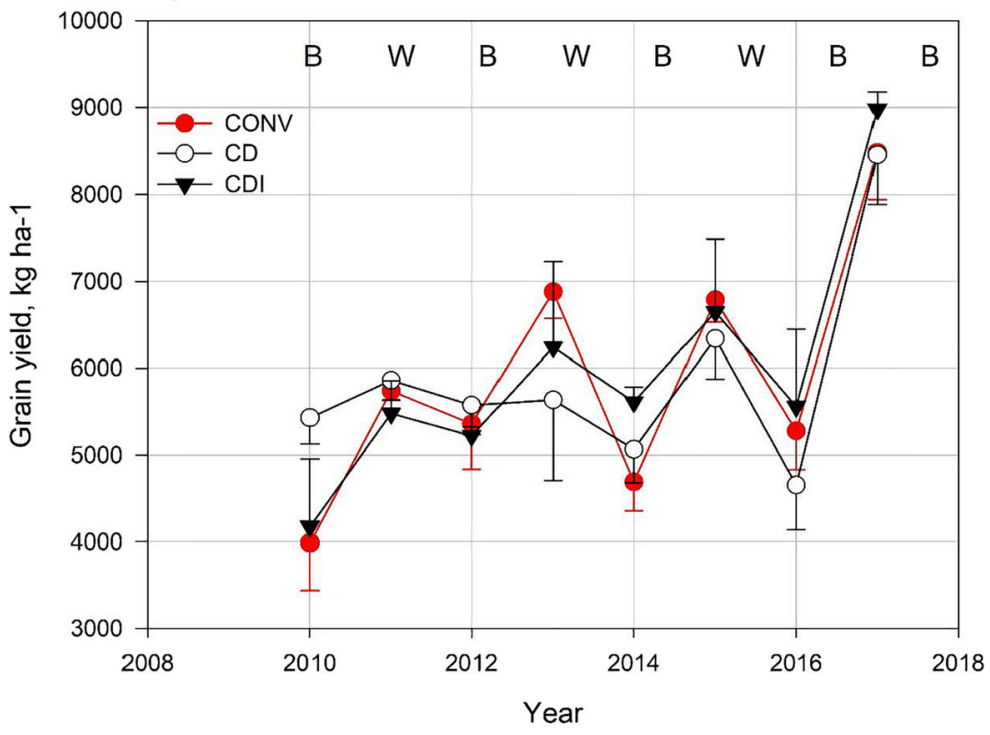

b)

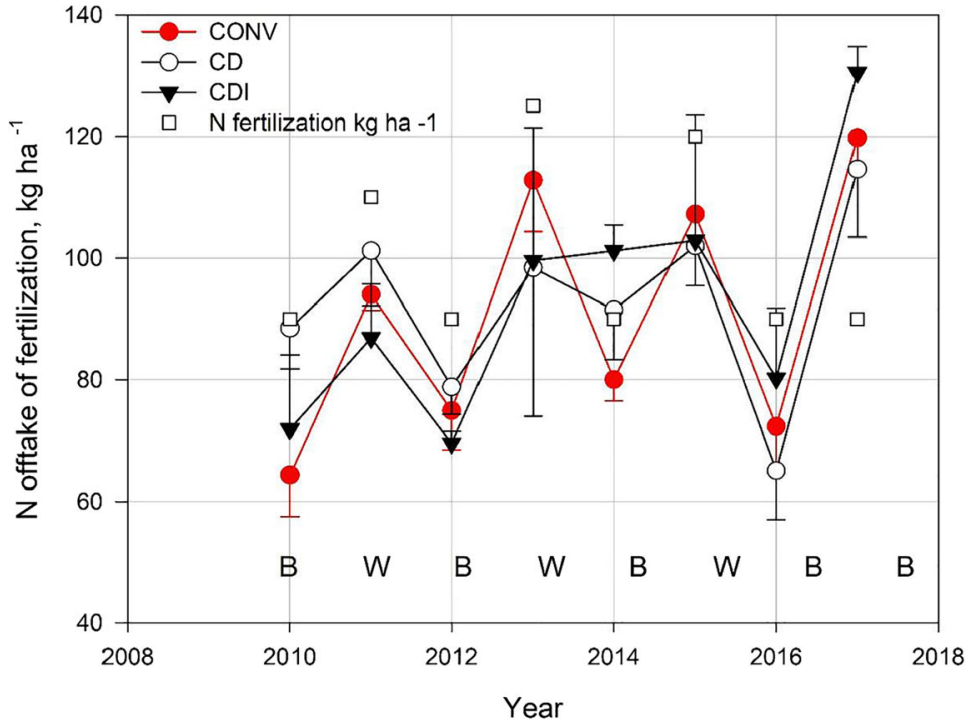

and in the upper part of the $\mathrm{Cg}$ (below $150 \mathrm{~cm}$ ). Thus, the increasing EC in discharge with falling GW suggests that the discharge predominantly consists of water coming from the $\mathrm{BCg}$ and $\mathrm{Cg}$ horizons. Applying the same reasoning, the increasing $\mathrm{NO}_{x}{ }^{-}-\mathrm{N}$ upon falling $\mathrm{GW}$ and increasing $\mathrm{EC}$ (Fig. 8) suggests that $\mathrm{NO}_{x}^{-}-\mathrm{N}$ also originates from the subsoil.

In spring discharge, $\mathrm{Ntot}$ and $\mathrm{NO}_{3}{ }^{-}-\mathrm{N}$ concentration in drainage water decreased steadily between 2010 and 2013 and more irregularly and more slowly thereafter (Fig. 9). In autumn 2010, there was an increase, and after 2012 a decrease, in Ntot concentration in drainage water. On average, $91 \%$ of Ntot consisted of inorganic $\mathrm{N}$ forms $\left(\mathrm{NO}_{3}{ }^{-}-\mathrm{N}, \mathrm{NO}_{2}{ }^{-}-\mathrm{N}\right.$, and $\left.\mathrm{NH}_{4}{ }^{+}-\mathrm{N}\right)$. Nitrate was the dominant $\mathrm{N}$ form, with $\mathrm{NH}_{4}{ }^{+}-\mathrm{N}$ comprising less than $1 \%$ of Ntot and with $\mathrm{NO}_{2}^{-}-\mathrm{N}$ concentrations being negligible. There was a tendency in autumn throughout the experimental period for Ntot concentrations to be higher in $\mathrm{CD}$ and CDI than CONV. In spring, the difference between the fields was less pronounced. The differences in Ntot were attributable to lower $\mathrm{NO}_{3}{ }^{-}-\mathrm{N}$ concentrations in water coming from $\mathrm{CONV}$. 
Fig. 6 Concentration of nitratenitrogen $\left(\mathrm{NO}_{3}{ }^{-}-\mathrm{N}\right)$ in grab samples of discharge from the conventional subsurface drainage (CONV), controlled drainage (CD), and controlled drainage with sub-irrigation (CDI) treatments. The solid line shows the results of continuous measurements of $\mathrm{NO}_{x}{ }^{-}-\mathrm{N}\left(\mathrm{NO}_{3}{ }^{-}-\mathrm{N}+\right.$ $\mathrm{NO}_{2}{ }^{-}-\mathrm{N}$ ) in a drainage well located in CDI. Gray represents discharge from CDI
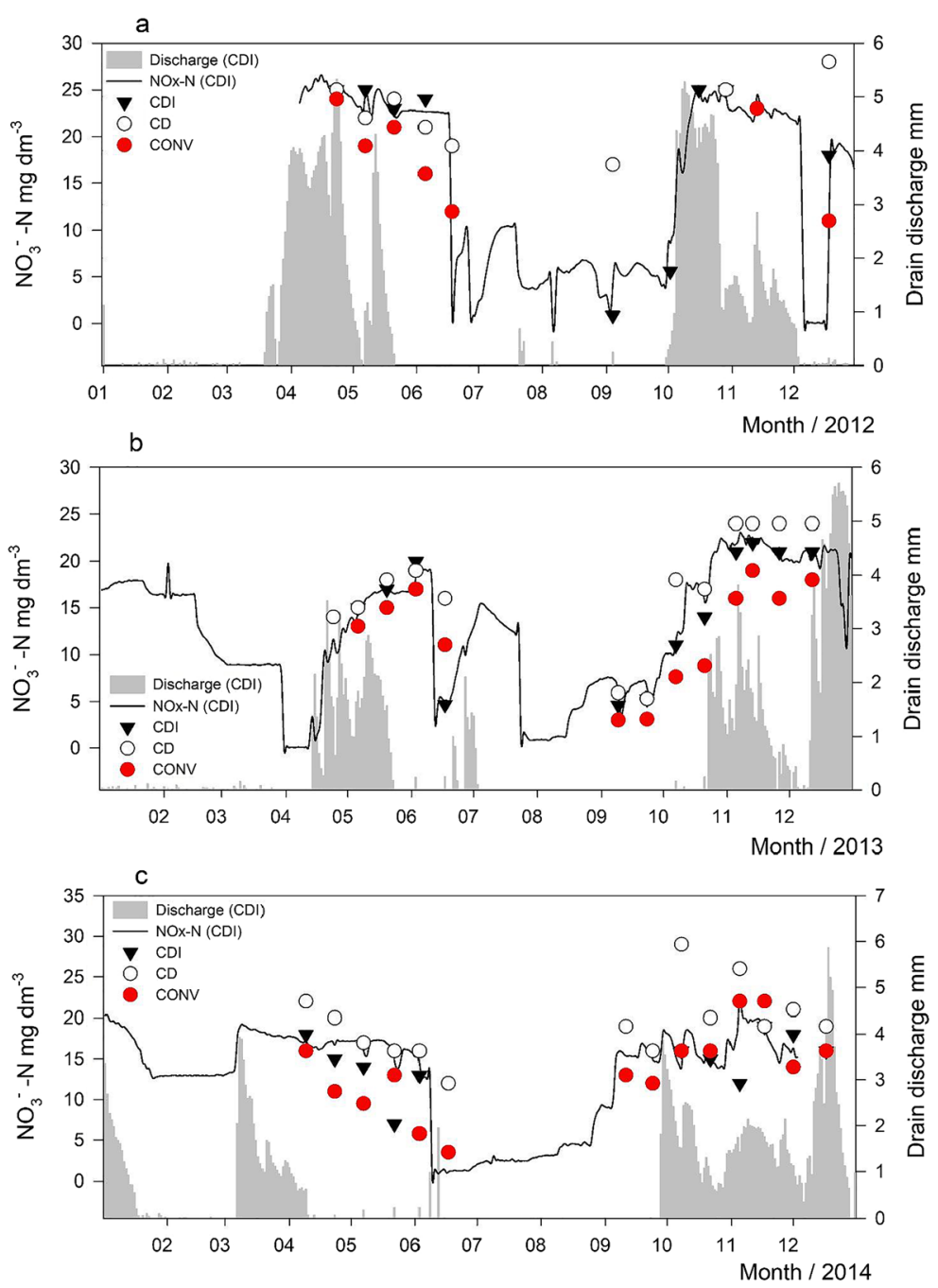

Nitrogen load

The annual variation in $\mathrm{N}$ loads within a given experimental year was much higher than that between the three fields. The annual Ntot load was $50 \mathrm{~kg} \mathrm{ha}^{-1}$ (range 35$71 \mathrm{~kg} \mathrm{ha}^{-1}$ ) in CONV, $52 \mathrm{~kg} \mathrm{ha}^{-1}$ (range 31-81 $\mathrm{kg} \mathrm{ha}^{-1}$ ) in CDI, and $63 \mathrm{~kg} \mathrm{ha}^{-1}$ (range 36-91 kg ha ${ }^{-1}$ ) in CD (Table 3). Thus, the loads calculated for CD were around $26 \%$ higher compared to CONV ( $p=0.0041)$ and CDI ( $p=0.0053)$. This difference was consistent and can be connected to the amount of discharge which was about $15 \%$ higher in CD than in CONV and CDI. The difference was apparent also in summer 2015 and 2017, when sub-irrigation could not be performed and the CDI field was thus managed like CD. Higher discharge (and Ntot load) can therefore be regarded as a characteristic of the particular field. There was a positive correlation $(r=0.65, p=0.0013$; excluding $2015 r=$ $0.81, p<0.001)$ between Ntot load and discharge, and a negative but non-significant correlation $(r=-0.39, p=$ 0.084 ) between Ntot load and $\mathrm{N}$ offtake in the harvested grain. The year 2016 was an outlier, with both Ntot load and $\mathrm{N}$ offtake in the harvested grain being small. In that year, a wet summer contributed to low yields and $\mathrm{N}$ offtake while a very dry autumn was conducive to low Ntot load. Excluding that year, the correlation between these variables increased to $r=-0.80(p<0.001)$.

There was a good match between the load estimates calculated on the basis of manual sampling and predominantly continuous sampling (Table 3 ). In 2013, in particular, when continuous measurement ran throughout the year, the estimates obtained from continuous 


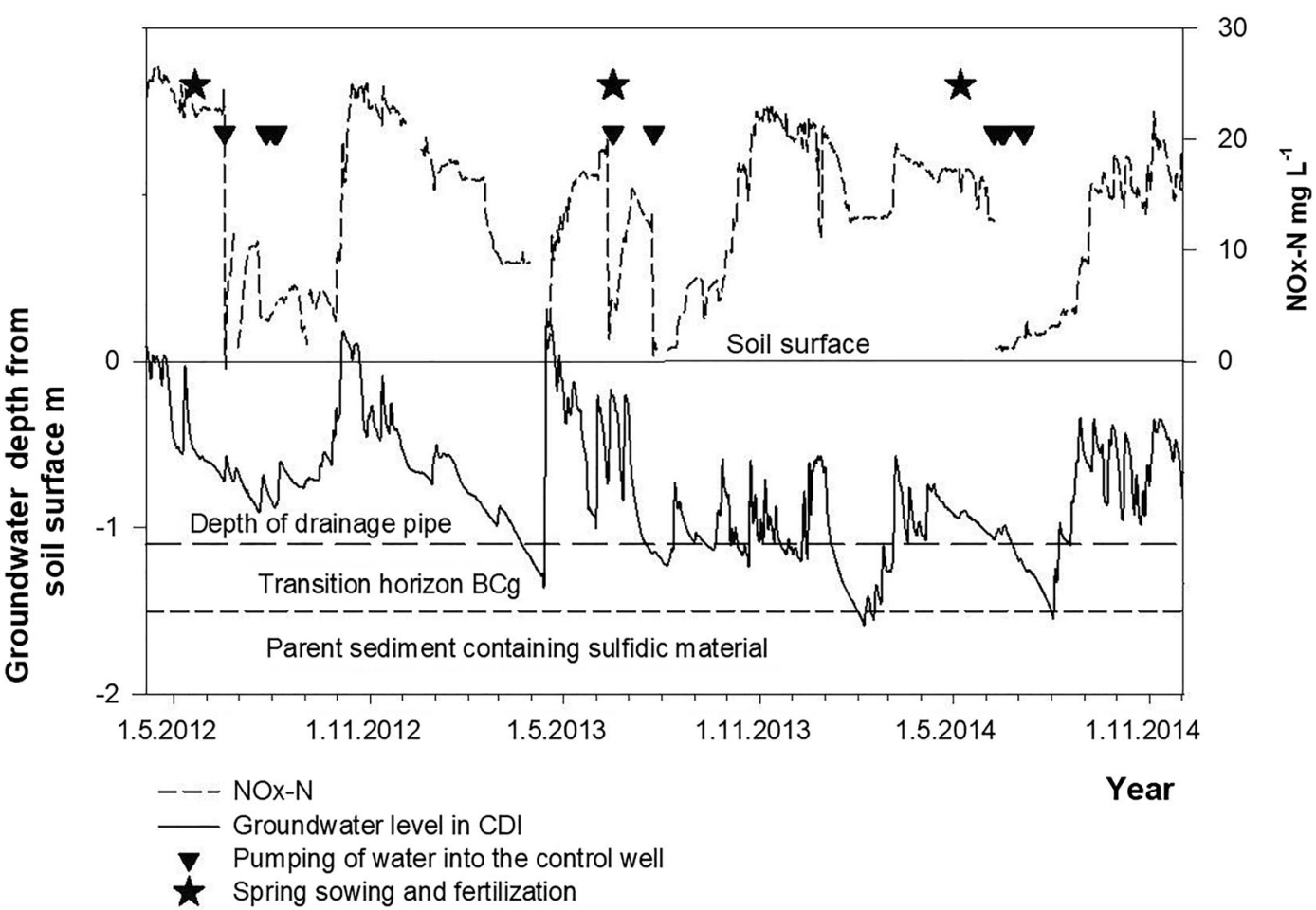

Fig. 7 Time series of continuously monitored nitrous oxides $\left(\mathrm{NO}_{x}{ }^{-}-\mathrm{N}\right)$ and groundwater in the period April 2012-Nov 2014. Triangles denote time of pumping water in the controlled drainage treatment with sub-irrigation (CDI) and stars the time of fertilization

sampling were $9 \%$ smaller than those derived from manual sampling. On this basis, it can be concluded that the annual Ntot load estimates based on manual sampling were within $\pm 10 \%$ of the correct value.

\section{Nitrous oxide emissions}

Mean daily emission rate of $\mathrm{N}_{2} \mathrm{O}$ in 2010-2014 was 55, 64, and $42 \mathrm{~g} \mathrm{~N}$ day $^{-1}$ in CONV, CD, and CDI, respectively. The fluxes of $\mathrm{N}_{2} \mathrm{O}$ peaked in early summer, but also at times of frost initiation, as in January 2011, and on sudden increases in soil moisture due to high GW, as in autumn 2011 (Fig. 10). The annual rate ranged from 7.9 to $28 \mathrm{~kg} \mathrm{~N} h a^{-1}$ (Table 4). Mixed model analysis suggested that over all years, $\mathrm{CD}$ and $\mathrm{CDI}$ lowered the $\mathrm{N}_{2} \mathrm{O}$ flux compared with the CONV treatment $(p=$ 0.0003 ) although the difference was evident only for CDI in summer 2014 (Fig. 10).

The concentration of $\mathrm{N}_{2} \mathrm{O}$ in the soil profile increased with increasing depth from 30 to $70 \mathrm{~cm}$ (Fig. 11). The CONV field generally showed the lowest concentration, and the $\mathrm{CD}$ field the highest, and a seasonal peak in $\mathrm{N}_{2} \mathrm{O}$ was observed in July. The flux measured from the adjacent chambers followed the pattern of the concentration changes in the $30-\mathrm{cm}$ layer.

In the 0-20-cm soil layer of CONV, maximum $\mathrm{N}_{2} \mathrm{O}$ production was observed at $\mathrm{pH} 5.3$ and maximum $\mathrm{N}_{2} \mathrm{O}$ $+\mathrm{N}_{2}$ at pH 6.8 (Fig. 12). Below pH 5, there was no $\mathrm{N}_{2}$ production whereas at $\mathrm{pH} 6.8$ most of the $\mathrm{N}$ production was emitted as $\mathrm{N}_{2}$. In the deeper soil layer, the maximum DEA was measured at $\mathrm{pH}$ values around 6 and the proportion of $\mathrm{N}_{2}$ in the total DEA was negligible at each $\mathrm{pH}$ level. The results with and without acetylene differed significantly in the topsoil $(p<0.05)$ but not in the deeper layer.

\section{Nitrogen balance}

A comprehensive $\mathrm{N}$ balance was estimated for the 2 years in which $\mathrm{N}_{2} \mathrm{O}$ emissions were measured (Table 4). Because straw was returned to the soil, straw $\mathrm{N}$ content (about $30 \mathrm{~kg} \mathrm{ha}^{-1}$ ) was not taken into account in the balance calculation. The grain contained $9-23 \mathrm{~kg} \mathrm{ha}^{-1}$ less $\mathrm{N}$ than was applied with fertilizer. Due to the abundant losses of $\mathrm{N}$ through leaching and emissions, the Ntot removal was clearly higher than the $\mathrm{N}$ addition rate. In both years, net removal of $\mathrm{N}$ was highest in the 
Fig. 8 Concentration of (left) nitrous oxides $\left(\mathrm{NO}_{x}^{-}-\mathrm{N}\right)$ and (right) electrical conductivity (EC) in discharge water, plotted against groundwater $(\mathrm{GW})$ depth in spring and autumn 2012-2014. The measurements were carried out in the controlled drainage with sub-irrigation (CDI) treatment
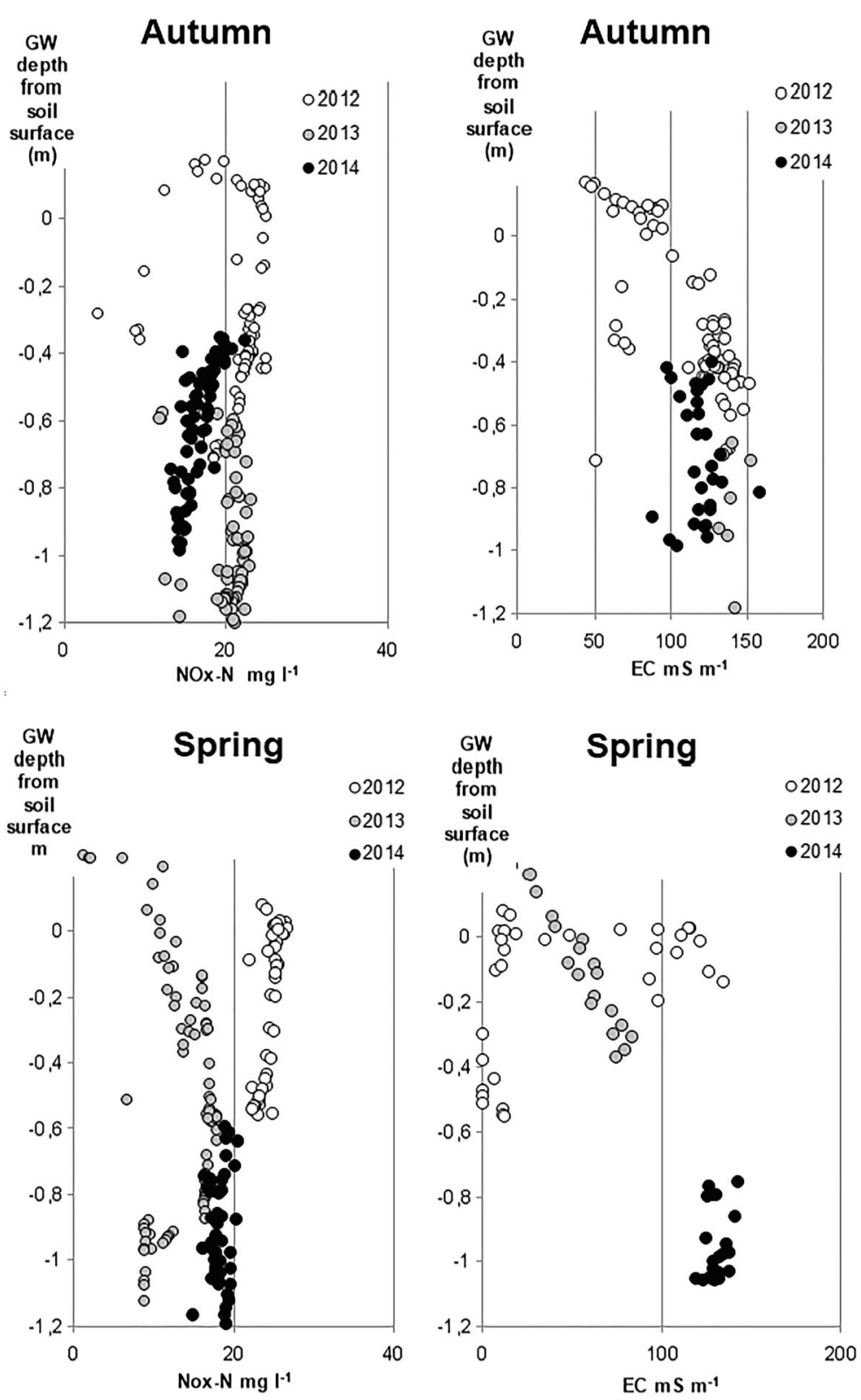

$\mathrm{CD}$ treatment where the $\mathrm{N}$ discharge was higher than that in the other two treatments.

During the entire period 2011-2017, leaching and N offtake in the harvested grain, both measured every year, averaged $150 \mathrm{~kg} \mathrm{ha}^{-1}$ (range 106-182 $\mathrm{kg} \mathrm{ha}^{-1}$ ), which represented $148 \%$ of $\mathrm{N}$ fertilization, i.e., $48 \mathrm{~kg} \mathrm{ha}^{-1}$ (range $16-80 \mathrm{~kg} \mathrm{ha}^{-1}$ ) more than what was applied in $\mathrm{N}$ fertilizers (see Table 3 and Fig. 5). Assuming the average $\mathrm{N}_{2} \mathrm{O}$ emissions of $16 \mathrm{~kg} \mathrm{ha}^{-1}$ also for 2012 2017 and including these in the calculation, net removal of $\mathrm{N}$ from the field was on average $64 \mathrm{~kg} \mathrm{ha}^{-1}$ (range
32-96 $\mathrm{kg} \mathrm{ha}^{-1}$ ), with the result being consistent from year to year. This shows that the study soil has a very high $\mathrm{N}$ supply capacity.

\section{Discussion}

Nitrogen stock in the soil, along with $\mathrm{N}$ fertilizers, is the source of mobile N. At $0-100 \mathrm{~cm}$ in soil at our study site, the Ntot stock $\left(19.5 \mathrm{t} \mathrm{ha}^{-1}\right)$ was equal to or larger than that reported for eight mineral soils of Denmark, Finland, 

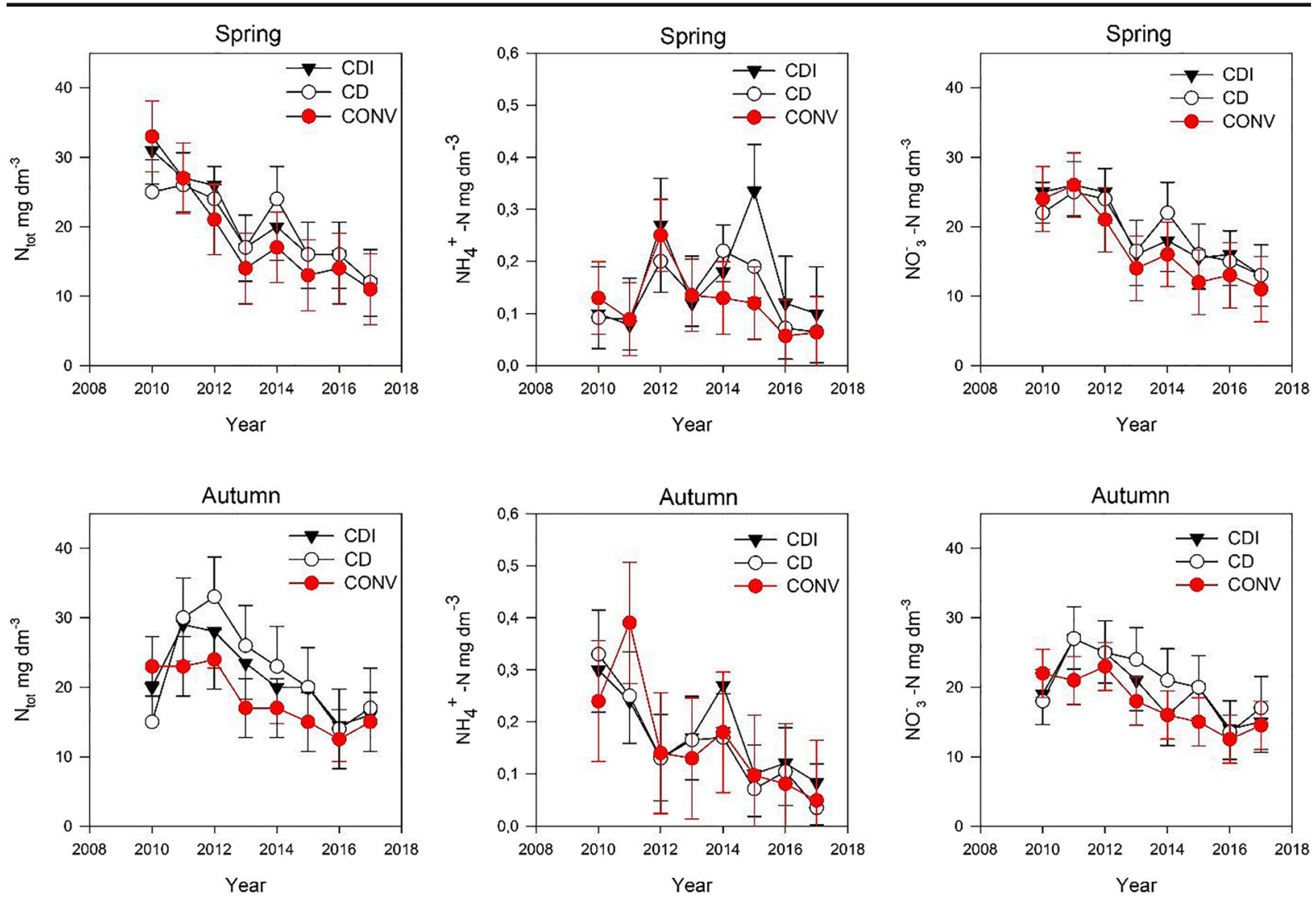

Fig. 9 Concentrations of (left) total nitrogen $(\mathrm{N})$, (center) ammonium- $\mathrm{N}\left(\mathrm{NH}_{4}{ }^{+}-\mathrm{N}\right)$, and (right) nitrate- $\mathrm{N}\left(\mathrm{NO}_{3}{ }^{-}-\right)$during (top) spring and (bottom) autumn runoff seasons, 2010-2017.

The error bars indicate standard deviation of concentrations in each season

Table 3 Annual discharge and loads of total nitrogen $(\mathrm{N})$ and inorganic $\mathrm{N}$ species. The column $\mathrm{NO}_{x}^{-}-\mathrm{N}$ shows load estimates based mainly on the results of continuous measurements in the controlled drainage with sub-irrigation (CDI) field. In 2015 and 2017, additional water was not pumped into CDI pipes, and CDI was treated similarly to $\mathrm{CD}$

\begin{tabular}{|c|c|c|c|c|c|c|c|c|c|c|c|c|c|c|c|c|}
\hline \multirow[t]{2}{*}{ Year } & \multicolumn{3}{|c|}{ Discharge, $\mathrm{mm}$} & \multicolumn{3}{|c|}{ Total N, kg ha ${ }^{-1}$} & \multicolumn{3}{|c|}{$\mathrm{NO}_{3}{ }^{-}-\mathrm{N}, \mathrm{kg} \mathrm{ha}{ }^{-1}$} & \multicolumn{3}{|c|}{$\mathrm{NH}_{4}^{+}-\mathrm{N}, \mathrm{kg} \mathrm{ha}^{-1}$} & \multicolumn{3}{|c|}{$\mathrm{NO}_{2}{ }^{-}-\mathrm{N} \mathrm{kg} \mathrm{ha}{ }^{-1}$} & \multirow[t]{2}{*}{$\mathrm{NO}_{x}-\mathrm{N} \mathrm{kg} \mathrm{ha}{ }^{-1}$} \\
\hline & CDI & $\mathrm{CD}$ & $\mathrm{CONV}$ & CDI & $\mathrm{CD}$ & CONV & CDI & $\mathrm{CD}$ & $\mathrm{CONV}$ & CDI & $\mathrm{CD}$ & CONV & CDI & $\mathrm{CD}$ & CONV & \\
\hline 2011 & 257 & 292 & 244 & 67 & 81 & 68 & 61 & 73 & 62 & 0.30 & 0.42 & 0.38 & 0.084 & 0.063 & 0.080 & - \\
\hline 2012 & 310 & 336 & 278 & 81 & 91 & 71 & 74 & 84 & 65 & 0.63 & 0.69 & 0.43 & 0.074 & 0.045 & 0.014 & $64^{\mathrm{a}}+(5)$ \\
\hline 2013 & 236 & 281 & 260 & 49 & 60 & 44 & 45 & 56 & 43 & 0.36 & 0.43 & 0.32 & 0.037 & 0.044 & 0.010 & $41^{\mathrm{b}}$ \\
\hline 2014 & 257 & 333 & 278 & 48 & 74 & 52 & 41 & 70 & 48 & 0.66 & 0.59 & 0.38 & 0.029 & 0.039 & 0.014 & $34^{\mathrm{c}}+(10)$ \\
\hline 2015 & 298 & 348 & 322 & 53 & 60 & 48 & 51 & 57 & 45 & 0.91 & 0.69 & 0.42 & 0.015 & 0.012 & 0.007 & - \\
\hline 2016 & 244 & 265 & 250 & 34 & 41 & 35 & 33 & 39 & 33 & 0.28 & 0.22 & 0.15 & 0.031 & 0.060 & 0.043 & - \\
\hline 2017 & 204 & 233 & 248 & 31 & 36 & 35 & 30 & 35 & 35 & 0.18 & 0.14 & 0.11 & 0.009 & 0.009 & 0.009 & - \\
\hline Mean & 258 & 298 & 268 & 52 & 63 & 50 & 48 & 59 & 47 & 0.47 & 0.45 & 0.31 & 0.040 & 0.039 & 0.025 & \\
\hline
\end{tabular}

${ }^{a}$ Continuous measurements between April 3 and December 31, 2012, and (in brackets) grab sampling between January 1 and April 2, 2012

${ }^{\mathrm{b}}$ Continuous measurements throughout the year 2013

${ }^{\mathrm{c}}$ Continuous measurements between January 1 and December 3, 2014, and (in brackets) grab sampling between December 4 and 31,2014 

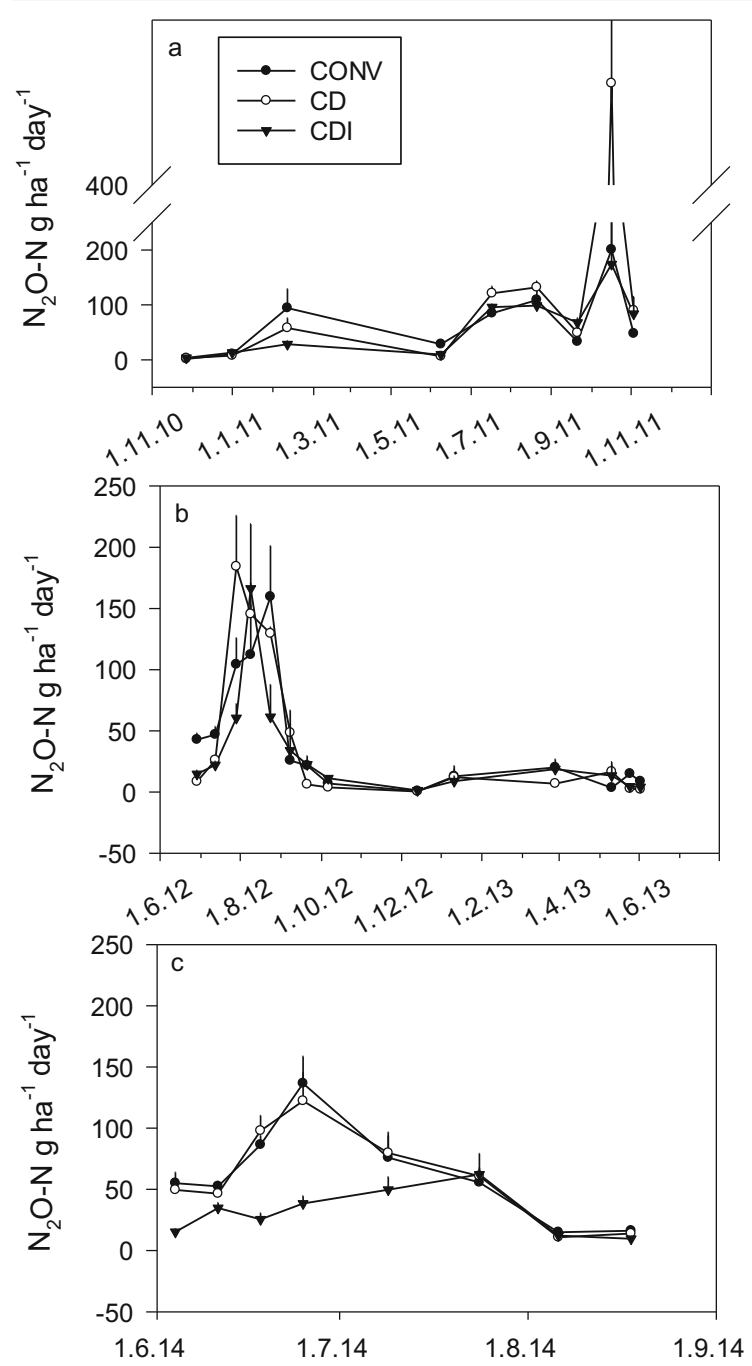

Fig. 10 Emissions of nitrous oxide $\left(\mathrm{N}_{2} \mathrm{O}\right)$ from the experimental plots in a 2010-2011, b 2012-2013, and c 2014. Fertilization events were 10.5.2011, 21.5.2012, 16-17.5.2013, and 8.5.2014

Table 4 Nitrogen balance $\left(\mathrm{kg} \mathrm{N} \mathrm{ha}^{-1}\right.$ year $\left.^{-1}\right)$ for the fields in the two years in which an estimate of annual $\mathrm{N}_{2} \mathrm{O}$ emissions was available. $\mathrm{CONV}=$ conventional subsurface drainage, $\mathrm{CD}=$ controlled drainage, $\mathrm{CDI}=$ controlled drainage with sub-irrigation

\begin{tabular}{lllllllll}
\hline & \multicolumn{2}{l}{2011, wheat } & & & \multicolumn{2}{l}{ 2012, barley } \\
\cline { 2 - 5 } \cline { 7 - 8 } & CONV & CD & CDI & & CONV & CD & CDI \\
\hline Fertilization & +110 & +110 & +110 & +90 & +90 & +90 \\
$\mathrm{~N}$ in grain & -87 & -101 & -94 & -70 & -79 & -75 \\
Leaching & -68 & -81 & -67 & -71 & -91 & -81 \\
$\mathrm{~N}_{2} \mathrm{O}$ & -24 & -28 & -20 & -10 & -9 & -8 \\
$\mathrm{~N}$ balance & -69 & -100 & -70 & -61 & -89 & -74 \\
\hline
\end{tabular}
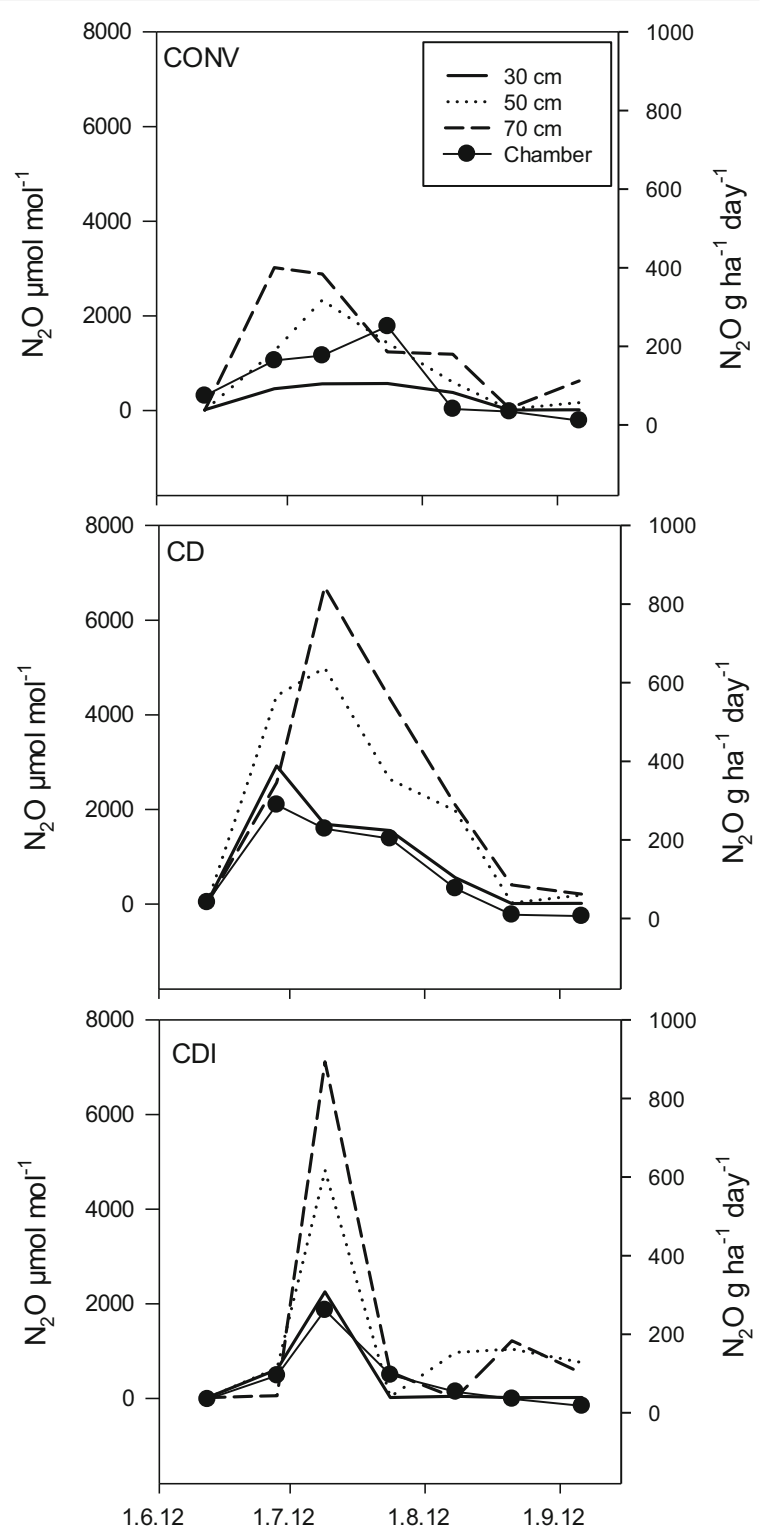

Fig. 11 Nitrous oxide $\left(\mathrm{N}_{2} \mathrm{O}\right)$ flux measured from chamber and the concurrent concentration of $\mathrm{N}_{2} \mathrm{O}$ in soil air at $30-\mathrm{cm}, 50-\mathrm{cm}$, and $70-\mathrm{cm}$ depth in summer 2012 in the conventional subsurface drainage (CONV), controlled drainage (CD), and controlled drainage with sub-irrigation (CDI) treatments

Norway, and Sweden (range 7.5-19.5 $\mathrm{t} \mathrm{ha}^{-1}$, mean $14.0 \mathrm{t}$ $\mathrm{ha}^{-1}$ ) (Lindén et al. 1992a). As it is closely associated with soil organic matter, the Ntot stock usually decreases with depth in non-AS mineral soils (Lindén et al. 1992a). This was not the case in the AS fields studied here, where the Ntot stock at $100-200 \mathrm{~cm}$ was $36 \%$ larger than that in the uppermost $100 \mathrm{~cm}$. In this respect, the Ntot stock in our AS soil resembles the value reported for other Finnish AS soils 

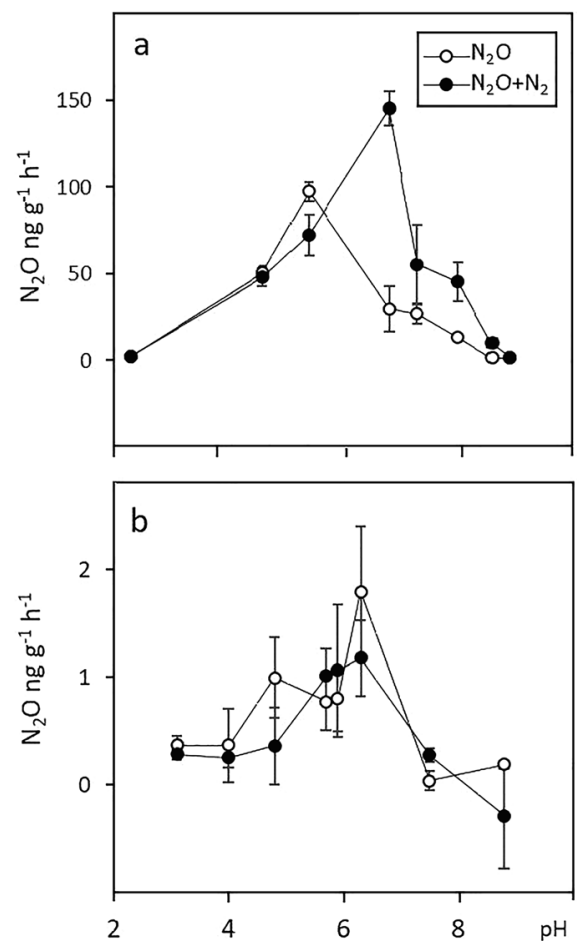

Fig. 12 Effect of $\mathrm{pH}$ on denitrifying enzyme activity (DEA) in layers 0-20 cm (a) and 80-100 cm (b)

and differs from non-AS soils (Paasonen-Kivekäs and YliHalla 2005; Šimek et al. 2011).

The large Ntot stock and low $\mathrm{C} / \mathrm{N}$ ratio suggest substantial potential for $\mathrm{N}$ mineralization throughout the soil profile, but waterlogging likely prevents $\mathrm{N}$ mineralization below the drainage pipes for most of the year. However, the GW level fell to $2-2.5 \mathrm{~m}$ periodically in summer, allowing aerobic reactions to take place. Together with near-neutral $\mathrm{pH}$ in those horizons that have not yet been acidified by the oxidation of sulfidic materials, the oxic conditions may enable periodic activity of the microbial community conducive to $\mathrm{N}$ mineralization.

Our experimental field seems not to contain an exceptionally large Nmin stock within the rooting zone. The Nmin stock (42.2-43.2 $\mathrm{kg} \mathrm{ha}^{-1}$ ) within the top $40 \mathrm{~cm}$ in 2010 and 2011 was at the upper end of the range found at $0-40 \mathrm{~cm}$ in eight mineral soils in Denmark, Finland, Norway, and Sweden (17-48 kg ha ${ }^{-1}$, mean $31 \mathrm{~kg} \mathrm{ha}^{-1}$ ) (Lindén et al. 1992b) and in the lower part of the range in 2012 and 2013. The annual differences in Nmin stock within the topsoil $(0-40 \mathrm{~cm})$ were attributable to $\mathrm{NO}_{3}{ }^{-}-\mathrm{N}$, while $\mathrm{NH}_{4}{ }^{+}-\mathrm{N}$ levels were more constant. In contrast, the Nmin stock increased with depth in the soil horizons that are mostly in the reduced state, with $\mathrm{NH}_{4}{ }^{+}-\mathrm{N}$ as the sole Nmin species in those horizons, agreeing with results from other AS soils of Finland (Paasonen-Kivekäs and Yli-Halla 2005; Šimek et al. 2011). The large Nmin stock in AS subsoil and parent sediment, besides the presence of sulfidic material, was confirmed as the most prominent difference between AS soils and non-AS soils.

High $\mathrm{N}$ concentration in drainage water during the first few years, twice as high as during the last years of monitoring, coincided with high Nmin in the top $40 \mathrm{~cm}$ of the soil. As found in the top $40 \mathrm{~cm}, \mathrm{NO}_{3}{ }^{-} \mathrm{N}$ was the dominant $\mathrm{N}$ form in drainage water. High initial concentrations may have been caused by oxidation-induced $\mathrm{N}$ mineralization associated with soil disturbance during construction of the experimental field in 2010. Peaks in $\mathrm{N}$ concentration in drainage water can also occur in practice in the year following ditching activities (Äijö et al. 2016). Thus, starting from 2012 , the $\mathrm{N}$ concentration in drainage water can be taken to represent the long-run loading from a non-disturbed AS soil. The $\mathrm{NO}_{3}{ }^{-}-\mathrm{N}$ concentration in discharge was at the same level as in 5.5-year monitoring of an AS soil at Ilmajoki about $60 \mathrm{~km}$ away from our study site (Bärlund et al. 2004). In that study, $\mathrm{NO}_{3}{ }^{-}-\mathrm{N}$ concentration was mostly around $12 \mathrm{mg} \mathrm{L}^{-1}$. In a 3-year monitoring (1991-1993) of spring cereal plots in a non-AS clay soil at Jokioinen, Finland, where the SOC content in the subsoil between 35 and $210 \mathrm{~cm}$ was $0.3-$ $0.5 \%$, the average Ntot concentration in drainage water was found to be only $6.1 \mathrm{mg} \mathrm{L}^{-1}$, and $85 \%$ of Ntot was in the form of $\mathrm{NO}_{3}{ }^{-}-\mathrm{N}$ (Turtola and Paajanen 1995). Likewise, in an agricultural mineral soil catchment in SW Norway, the average $\mathrm{NO}_{3}{ }^{-}-\mathrm{N}$ concentration in 1994 2016 was $4.3 \mathrm{mg} \mathrm{L}^{-1}$, comprising $78 \%$ of Ntot concentration (Chen and Bechmann 2019). The soil at our study site thus produced drainage water with substantially higher $\mathrm{N}$ concentrations than non-AS soils.

In this study, Ntot load through drainage pipes averaged $48 \mathrm{~kg} \mathrm{ha}^{-1}$ in 2012-2017, while annual load from the three individual fields were $31-91 \mathrm{~kg} \mathrm{ha}^{-1}$. Even the lowest annual $\mathrm{N}$ loads were at least double those from a clay soil cropped with spring cereals in a 7-year study in Jokioinen, Finland (Jaakkola 1984), or estimated as a specific $\mathrm{N}$ load from agricultural land in Finland $(15 \mathrm{~kg}$ $\mathrm{ha}^{-1}$; Tattari et al. 2017). Owing to the different water management systems in the fields, the $\mathrm{Cg}$ horizon was exposed to oxic conditions for a longer time in CONV than in $\mathrm{CD}$ and CDI. However, although the time available for mineralization of organic matter was shorter in $\mathrm{CD}$ and $\mathrm{CDI}$, $\mathrm{N}$ leaching was at the same level in CDI as in 
CONV, while the more abundant leaching from CD can be explained by the higher amount of discharge. This outcome was surprising, because in other studies on $\mathrm{CD}$ or CDI in non-AS soils that probably had low Nmin stocks in the subsoil, $\mathrm{N}$ leaching declined significantly under these water management practices due to decreased runoff (e.g., Evans et al. 1995; Woli et al. 2010; Carstensen et al. 2019). Moreover, it is likely that the large Nmin stock already present in the soil influenced $\mathrm{N}$ leaching more than production of new Nmin by mineralization. Our results thus confirmed hypothesis 1 , of abundant $\mathrm{N}$ leaching from this AS soil, but did not support hypothesis 3, of decreased $\mathrm{N}$ leaching with elevated GW level.

We were unable to clearly identify the soil horizon(s) acting as the main sources of the large $\mathrm{N}$ load entering drainage waters. The high concentration of Nmin in the top $40 \mathrm{~cm}$ of soil likely contributed to the abundant $\mathrm{N}$ load during the first few years explaining at least partly the declining trend in $\mathrm{N}$ loads during the experimental period. An influence of subsoil Nmin reserves is suggested by the finding that, whenever GW dropped into the subsoil, discharge thereafter contained a high $\mathrm{NO}_{x}^{-}-\mathrm{N}$ load. The explanation may lie in the large stock of $\mathrm{NH}_{4}{ }^{+}-\mathrm{N}$ in the anoxic subsoil. If discharge water contains $\mathrm{N}$ originating from this $\mathrm{NH}_{4}{ }^{+}-\mathrm{N}$ stock, nitrification must have occurred in situ in the near-neutral $\mathrm{Cg}$ horizon during the oxic periods in summer or at some stage of the transport process. When saturated conditions return, the $\mathrm{NO}_{3}{ }^{-}-\mathrm{N}$ formed and dissolved in pore water can be transported into the drainage pipes above and out of the soil, explaining the high $\mathrm{N}$ load to drainage waters.

Mean flux of $\mathrm{N}_{2} \mathrm{O}\left(54 \mathrm{~g} \mathrm{~N} \mathrm{ha}^{-1}\right.$ day $^{-1}$ ) was high compared with that in Finnish mineral soils in general, where the mean emission rate with annual crops is around $10 \mathrm{~g} \mathrm{~N} \mathrm{ha}^{-1}$ day $^{-1}$ (Regina et al. 2013). It was also high compared with organic soils, where a typical rate in annual crop cultivation is $30 \mathrm{~g} \mathrm{~N} \mathrm{ha}^{-1}$ day $^{-1}$ (Maljanen et al. 2007). Extremely high $\mathrm{N}_{2} \mathrm{O}$ emissions (up to $60 \mathrm{~kg}$ $\mathrm{N}_{2} \mathrm{O}-\mathrm{N} \mathrm{ha}{ }^{-1}$ ) from AS soils have also been found in Australia (Denmead et al. 2010) and Denmark (Petersen et al. 2012). The annual flux rates at our site $(8-28 \mathrm{~kg}$ $\mathrm{N}_{2} \mathrm{O}-\mathrm{N}$ ha ${ }^{-1}$ ) were based on only 9-15 measurements per year and can be considered indicative rather than absolute. However, the high values found in all three growing seasons indicate that the abundant $\mathrm{N}$ stock in these soils is a major source of $\mathrm{N}$ to watercourses and to the atmosphere, supporting our hypothesis 2 .

Hypothesis 4, that keeping the sulfidic layer inundated decreases $\mathrm{N}_{2} \mathrm{O}$ emissions, was supported by the data, but the effect was not consistent over the years. Significant production of $\mathrm{N}_{2} \mathrm{O}$ usually requires conditions allowing both nitrification and denitrification to occur simultaneously, with the final emission rate depending on the proportions of $\mathrm{N}_{2} \mathrm{O}$ and $\mathrm{N}_{2}$ in the end products of denitrification (Bollmann and Conrad 1998; Davidson 1991). Inundation can reduce $\mathrm{N}_{2} \mathrm{O}$ emissions via two potential mechanisms: (i) by retarding nitrification in the layer with high $\mathrm{NH}_{4}{ }^{+}-\mathrm{N}$ content and (ii) by extending the layer supporting $\mathrm{N}_{2} \mathrm{O}$ reduction to $\mathrm{N}_{2}$. The finding that the highest $\mathrm{N}_{2} \mathrm{O}$ concentration in soil air was measured at the lowest depth monitored $(70 \mathrm{~cm})$ suggests that the source of $\mathrm{NO}_{3}{ }^{-}-\mathrm{N}$ was in the deeper soil layers where nitrification may occur during drought periods and the $\mathrm{NO}_{3}{ }^{-}-\mathrm{N}$ formed can be available for further denitrification as the GW level rises. The active production zone of $\mathrm{N}_{2} \mathrm{O}$ was typically close to the GW depth, in the zone of varying moisture conditions, as also found in a study on a buffer wetland (Saari et al. 2013).

High emissions of $\mathrm{N}_{2} \mathrm{O}$ have also been linked to more abundant microbial populations in AS soils than nonAS mineral soils, at least in the subsoil (Šimek et al. 2011, 2014). In our soil, however, the basal respiration rates were lower (data not shown) than reported by Šmek et al. (2014). The denitrifying enzyme activity (DEA) was also lower than that in the AS soil studied by Čuhel and Šimek (2011). Production of $\mathrm{N}_{2} \mathrm{O}$ could also be purely chemical, in which case $\mathrm{N}_{2} \mathrm{O}$ would be formed from hydroxylamine or nitrite especially in acid soils (Zhu-Barker et al. 2015). This was suggested as a likely mechanism in a Danish AS soil (Taghizadeh-Toosi et al. 2019). However, in our soil, nitrite was likely present only in negligible amounts as its concentration in drainage water was low. The concentration measurements on soil air suggested that there was high $\mathrm{N}_{2} \mathrm{O}$ production in soil below $30 \mathrm{~cm}$, and thus the low pH (3.8-4.8) in the $\mathrm{Bg}$ and $\mathrm{BCg}$ horizons may be partly responsible for the high $\mathrm{N}_{2} \mathrm{O}$ emissions. Low $\mathrm{pH}$ inhibits $\mathrm{N}_{2} \mathrm{O}$ reductase, which increases the proportion of $\mathrm{N}_{2} \mathrm{O}$ in the end products of denitrification (Thomsen et al. 1994). This appears to be a plausible explanation for the high $\mathrm{N}_{2} \mathrm{O}$ emissions in our study, and the DEA results showed lack of $\mathrm{N}_{2}$ production at the lowest $\mathrm{pH}$ levels. It is also possible that the microbial populations in the subsoil lack $\mathrm{N}_{2} \mathrm{O}$ reductase in general, as the DEA results showed a total absence of $\mathrm{N}_{2}$ within the end products of denitrification in the subsoil. Only around $65 \%$ of denitrifying organisms carry $\mathrm{N}_{2} \mathrm{O}$ reductase (Philippot et al. 2011) and another possible explanation for the 
high $\mathrm{N}_{2} \mathrm{O}$ emissions could be that such bacteria dominate in the study soil, but this could not be verified from the results.

Grain yields on the study soil (mean $6200 \mathrm{~kg} \mathrm{ha}^{-1}$ for wheat and $5800 \mathrm{~kg} \mathrm{ha}^{-1}$ for barley) far exceeded the national average yields of these crops (3700 and $3500 \mathrm{~kg}$ $\mathrm{ha}^{-1}$, respectively) and resulted in high $\mathrm{N}$ uptake. The harvested grain and straw contained more $\mathrm{N}$ than was applied in the fertilizer, e.g., the $\mathrm{N}$ content of grains alone was on average $92 \%$ (annual range $81-135 \%$ ) of the $\mathrm{N}$ dose supplied by fertilizer. This exceeds the $75-78 \%$ commonly reported for spring cereals in Finland at similar fertilization levels (Esala and Larpes 1986; Rajala et al. 2007). However, in our experimental setup, there were no plots without $\mathrm{N}$ fertilization, preventing us from drawing firm conclusions on the role of ample native $\mathrm{N}$ supply in high yields and $\mathrm{N}$ offtake, which may also be attributable to good soil structure and favorable water management.

When $\mathrm{N}$ losses to water and to the atmosphere were taken into account, the difference in $\mathrm{N}$ output between our AS soil and non-AS soils was even more drastic. In our experiment, $\mathrm{N}$ leaching plus $\mathrm{N}$ offtake in the harvested grain exceeded $\mathrm{N}$ fertilization in every year studied, the average excess being $48 \mathrm{~kg} \mathrm{ha}^{-1}$ while in an 11year field experiment on a non-AS clay soil in Jokioinen, Finland, the harvested grain and drainage waters contained $27 \mathrm{~kg} \mathrm{ha}^{-1}$ less $\mathrm{N}$ than was applied in fertilizer (Salo and Turtola 2006). There was thus a $75 \mathrm{~kg} \mathrm{ha}^{-1}$ difference in $\mathrm{N}$ output between the two experiments. The difference increases to $89 \mathrm{~kg} \mathrm{ha}^{-1}$ when considering the average $\mathrm{N}_{2} \mathrm{O}-\mathrm{N}$ emissions of $16 \mathrm{~kg} \mathrm{ha}^{-1}$ in our experiment and $3.5 \mathrm{~kg} \mathrm{ha}^{-1}$ in conventional cereal cultivation (Syväsalo et al. 2006). These results demonstrate that AS soils contain an exceptionally large $\mathrm{N}$ stock which supplies $\mathrm{N}$ to the crop and is a source of $\mathrm{N}$ emissions and leaching.

\section{Conclusions}

Large Ntot and Nmin stocks, particularly in subsoil subjected to alternating redox conditions, are a specific characteristic of AS soils compared with non-AS mineral soils. In the AS soil in this study, abundant transport of $\mathrm{N}$ was shown to occur through different ways, including offtake in the harvested crop, leaching, and gaseous losses, all exceeding those in non-AS mineral soils and resulting in negative $\mathrm{N}$ balance. There was a large $\mathrm{NH}_{4}{ }^{+}-\mathrm{N}$ stock in the subsoil, and it may contribute to $\mathrm{N}$ fluxes through nitrification during short oxic periods, with subsequent transport of $\mathrm{NO}_{3}{ }^{-}-\mathrm{N}$ or denitrification to $\mathrm{N}_{2} \mathrm{O}$ or $\mathrm{N}_{2}$. The $\mathrm{N}_{2} \mathrm{O}$ emissions from the study soil were extremely high, which is potentially explained by lack of $\mathrm{N}_{2} \mathrm{O}$ reduction in deeper soil layers due to low $\mathrm{pH}$ or unfavorable composition of the microbial population. The study provided only moderate evidence that manipulation of groundwater level by controlled drainage or sub-irrigation can reduce $\mathrm{N}$ mineralization and $\mathrm{N}_{2} \mathrm{O}$ emissions and thus alleviate some environmental consequences of cultivation of AS soil. Having identified the large $\mathrm{N}$ flows and stocks, we now need to monitor the Nmin stock spatially and temporally in more detail. Relationships between the large $\mathrm{NH}_{4}{ }^{+}-\mathrm{N}$ stock, $\mathrm{NO}_{3}{ }^{-}-\mathrm{N}$ leaching, $\mathrm{N}_{2} \mathrm{O}$ emissions, and $\mathrm{N}$ offtake by the crop should be experimentally investigated and presence of $\mathrm{N}_{2} \mathrm{O}$ reductase in the microbial population needs to be examined. Whether $\mathrm{N}$ fertilization rates to AS soils can be lowered is also an urgent and practical topic for further research. Our results strongly suggest that the large $\mathrm{N}$ stock in AS soils should be taken into account when planning fertilization.

Acknowledgments The experimental field was established and the study started during the EU-Life+ project CATERMASS (2010-2012) (LIFE08ENV/FIN/000609), and continued within the projects BEFCASS (2013-2015), financed by the Ministry of Agriculture and Forestry, and VIMLA (2015-2018), financed by the EU Botnia-Atlantica Interreg program. This work was also supported by the Oiva Kuusisto Foundation (grants 20.4.2009 and 5.5.2015), Maaja vesitekniikan tuki ry, and Drainage Foundation sr. We thank Mr. Rainer Rosendahl for his valuable work during the project, and the personnel at the ELY Centre in Vaasa and the Natural Resources Institute Finland (Luke) for their contribution in the data collection and analyses. Special thanks to farmers Arne Lervik, Tom Backlund, and Stefan Östman for their cooperation in the field.

Funding Open access funding provided by University of Helsinki including Helsinki University Central Hospital.

Open Access This article is licensed under a Creative Commons Attribution 4.0 International License, which permits use, sharing, adaptation, distribution and reproduction in any medium or format, as long as you give appropriate credit to the original author(s) and the source, provide a link to the Creative Commons licence, and indicate if changes were made. The images or other third party material in this article are included in the article's Creative Commons licence, unless indicated otherwise in a credit line to the material. If material is not included in the article's Creative Commons licence and your intended use is not permitted by statutory regulation or exceeds the permitted use, you will need to obtain permission directly from the copyright holder. To view a copy of this licence, visit http://creativecommons.org/licenses/by/4.0/. 


\section{References}

Äijö, H., Paasonen-Kivekäs, M., Myllys, M., Nurminen, J., Turunen, M., Salo, H., Warsta, L., Koivusalo, H., Sikkilä, M., Alakukku, L., \& Puustinen, M. (2016). The effect of additional subsurface drainage on water discharge and nutrient load on clay soil. In J. F. Strock (Ed.), Proceedings of the 10th International Drainage Symposium 7-9 September, 2016 Minneapolis, Minnesota. St Joseph: American Society of Agricultural and Biological Engineers ASABE.

Åström, M., \& Björklund, A. (1997). Geochemistry and acidity of sulphide-bearing postglacial sediments of western Finland. Environmental Geochemistry and Health, 19, 155-164.

Åström, M., Österholm, P., Bärlund, I., \& Tattari, S. (2007). Hydrochemical effects of surface liming, controlled drainage and lime-filter drainage on boreal acid sulfate soils. Water, Air, and Soil Pollution, 179, 107-116.

Bärlund, I., Tattari, S., Yli-Halla, M., \& Åström, M. (2004). Effects of sophisticated drainage techniques on groundwater level and drainage water quality on acid sulphate soils: final report of the HAPSU project. The Finnish Environment, 732, 1-68 https://helda.helsinki.fi/handle/10138/40557.

Bianchi, T. S., Engelhaupt, E., Westman, P., Andren, T., \& Elmgren, C. R. R. (2000). Cyanobacterial blooms in the Baltic Sea: natural or human-induced? Limnology and Oceanography, 45, 716-726.

Bollmann, A., \& Conrad, R. (1998). Influence of $\mathrm{O}_{2}$ availability on $\mathrm{NO}$ and $\mathrm{N}_{2} \mathrm{O}$ release by nitrification and denitrification in soils. Global Change Biology, 4, 387-396.

Boman, A., Åström, M., \& Fröjdö, S. (2008). Sulfur dynamics in boreal acid sulfate soils rich in metastable iron sulfide - the role of artificial drainage. Chemical Geology, 255, 68-75.

Brunet, R. C., \& Garcia-Gil, L. J. (1996). Sulfide-induced dissimilatory nitrate reduction to ammonia in anaerobic freshwater sediments. FEMS Microbiology Ecology, 21, 131-138.

Carstensen, M. V., Børgesen, C. D., Ovensen, N. B., Poulsen, J. R., Hvid, S. K., \& Kronvang, B. (2019). Controlled drainage as a targeted mitigation measure for nitrogen and phosphorus. Journal of Environmental Quality, 48, 677-685.

Chen, X., \& Bechmann, M. (2019). Nitrogen losses from two contrasting agricultural catchments in Norway. Royal Society Open Science, 6, 190490.

Čuhel, J., \& Šimek, M. (2011). Proximal and distal control by $\mathrm{pH}$ of denitrification rate in a pasture soil. Agriculture, Ecosystems \& Environment, 141, 230-233.

Davidson, E. A. (1991). Fluxes of nitrous oxide and nitric oxide from terrestrial ecosystems. In J. E. Rogers \& W. B. Whitman (Eds.), Microbial production and consumption of greenhouse gases: methane, nitrogen oxides and halomethanes (pp. 219-236). Washington, DC: American Society for Microbiology.

Denmead, O. T., Macdonald, B. C. T., Bryant, G., Naylor, T., Wilson, S., Griffith, D. W.-T., Wang, W. J., Salter, B., White, I., \& Moody, P. W. (2010). Emissions of methane and nitrous oxide from Australian sugarcane soils. Agricultural and Forest Meteorology, 150, 748-756.

Dent, D. L., \& Pons, L. J. (1995). A world perspective on acid sulphate soils. Geoderma, 67, 263-276.

Esala, M. J. (1995). Changes in the extractable ammoniumnitrogen and nitrate-nitrogen contents of soil samples during freezing and thawing. Communications in Soil Science and Plant Analysis, 26, 61-68.

Esala, M., \& Larpes, G. (1986). Effect of the placement technique and amount of fertilizer on spring wheat and barley grown on clay soils. Annales Agriculturae Fenniae, 25, 159-175.

Evans, R. O., Skaggs, W., \& Gilliam, J. W. (1995). Controlled versus conventional drainage effects on water quality. Journal of Irrigation and Drainage Engineering, 121, 271-276.

ISO 11905-1:1997. (1997). Water quality - determination of nitrogen - part 1: method using oxidative digestion with peroxodisulfate. International Organization for Standardization.

IUSS Working Group WRB. (2015). World Reference Base for Soil Resources 2014, update 2015. International soil classification system for naming soils and creating legends for soil maps. World Soil Resources Reports 106. Rome: FAO.

Jaakkola, A. (1984). Leaching losses of nitrogen from a clay soil under grass and cereal crops in Finland. Plant and Soil, 76, 59-66.

Jiang, Q., Qi, Z., Madramootoo, C. A., \& Crézé, C. (2019). Mitigating greenhouse gas emissions in subsurface-drained field using RZWQM2. Science of the Total Environment, 646, 377-389.

Johnston, S. G., Burton, E. D., Aaso, T., \& Tuckerman, G. (2014). Sulfur, iron and carbon cycling following hydrological restoration of acidic freshwater wetlands. Chemical Geology, 371, 9-26.

Kanerva, T., Regina, K., Rämö, K., Ojanperä, K., \& Manninen, S. (2007). Fluxes of $\mathrm{N}_{2} \mathrm{O}, \mathrm{CH}_{4}$ and $\mathrm{CO}_{2}$ in a meadow ecosystem exposed to elevated ozone and carbon dioxide for three years. Environmental Pollution, 145, 818-828.

Lindén, B., Lyngstad, I., Sippola, J., Soegaard, K., \& Kjellerup, V. (1992a). Nitrogen mineralization during the growing season: 1. Contribution to the nitrogen supply of spring barley. Swedish Journal of Agricultural Research, 22, 3-12.

Lindén, B., Lyngstad, I., Sippola, J., Soegaard, K., \& Kjellerup, V. (1992b). Nitrogen mineralization during the growing season: 2. Influence of soil organic matter content, and effect on optimum nitrogen fertilization of spring barley. Swedish Journal of Agricultural Research, 22, 49-60.

Macdonald, B. C. T., Denmead, O. T., White, I., \& Bryant, G. (2011). Gaseous nitrogen losses from coastal acid sulfate soils: a short-term study. Pedosphere, 21, 197-206.

Maljanen, M., Hytönen, J., Mäkiranta, P., Alm, J., Minkkinen, K., Laine, J., \& Martikainen, P. J. (2007). Greenhouse gas emissions from cultivated and abandoned organic croplands in Finland. Boreal Environment Research, 12, 133-140.

Öborn, I. (1989). Properties and classification of some acid sulfate soils in Sweden. Geoderma, 45, 197-219.

Österholm, P., \& Åström, M. (2002). Spatial trends and losses of major and trace elements in agricultural acid sulphate soils distributed in the artificially drained Rintala area, W. Finland. Applied Geochemistry, 17, 1209-1218.

Österholm, P., Virtanen, S., Rosendahl, R., Uusi-Kämppä, J., Ylivainio, K., Yli-Halla, M., Mäensivu, M., \& Turtola, E. (2015). Groundwater management of sulfide bearing farmlands using by-pass flow prevention and subsurface irrigation. Acta Agriculturae Scandinavica Section B Soil and Plant Science, 65(Supplement 1), 110-120.

Paasonen-Kivekäs, M., \& Yli-Halla, M. (2005). A comparison of nitrogen and carbon reserves in acid sulphate and non acid sulphate soils in western Finland. Agricultural and Food Science, 14, 57-69.

Palko, J. (1994). Acid sulphate soils and their agricultural and environmental problems in Finland. $\mathrm{PhD}$ thesis. University of Oulu, Acta Universitatis, Ouluensis, C 75, 58 pp. 
Petersen, S. O., Hoffmann, C. C., Schafer, C., Blicher-Mathiesen, G., Elsgaard, L., Kristensen, K., Larsen, S. E., Torp, S. B., \& Greve, M. H. (2012). Annual emissions of $\mathrm{CH}_{4}$ and $\mathrm{N}_{2} \mathrm{O}$, and ecosystem respiration, from eight organic soils in Western Denmark managed by agriculture. Biogeosciences, 9, 403422.

Philippot, L., Andert, J., Jones, C. M., Bru, D., \& Hallin, S. (2011). Importance of denitrifiers lacking the genes encoding the nitrous oxide reductase for $\mathrm{N}_{2} \mathrm{O}$ emissions from soil. Global Change Biology, 17, 1497-1504.

Postma, D., Boesen, C., Kristiansen, H., \& Larsen, F. (1991). Nitrate reduction in an unconfined sandy aquifer: water chemistry, reduction processes, and geochemical modeling. Water Resources Research, 27, 2027-2045.

Rajala, A., Peltonen-Sainio, P., Kauppila, R., Wilhelmson, A., Reinikainen, P., \& Kleemola, J. (2007). Within-field variation in grain yield, yield components and quality traits of tworow barley. Journal of Agricultural Science, 145, 445-454.

Regina, K., Kaseva, J., \& Esala, M. (2013). Emissions of nitrous oxide from boreal agricultural mineral soils - statistical models based on measurements. Agriculture, Ecosystems \& Environment, 164, 131-136.

Rekolainen, S. (1989). Phosphorus and nitrogen load from forest and agricultural areas in Finland. Aqua Fennica, 19, 95-107.

Rickard, D., \& Luther III, G. W. (2007). Chemistry of iron sulfides. Chemical Reviews, 107, 514-562.

Ritzema, H. P., \& Stuyt, L. C. P. M. (2015). Land drainage strategies to cope with climate change in the Netherlands. Acta Agriculturae Scandinavica Section B Soil and Plant Science, 65(Supplement 1), 80-92.

Saari, P., Saarnio, S., Heinonen, J., \& Alm, J. (2013). Emissions and dynamics of $\mathrm{N}_{2} \mathrm{O}$ in a buffer wetland receiving water flows from a forested peatland. Boreal Environment Research, 18, 180-164.

Salo, T., \& Turtola, E. (2006). Nitrogen balance as indicator of nitrogen leaching in Finland. Agriculture, Ecosystems \& Environment, 113, 98-107.

Schippers, A., \& Jørgensen, B. (2002). Biogeochemistry of pyrite and iron sulfide oxidation in marine sediments. Geochimica et Cosmochimica Acta, 66, 85-92.

SFS-EN 27888:en. (1994). Water quality. Determination of electrical conductivity (ISO 7888:1985). Finnish Standards Association.

SFS-EN ISO 11732:en. (2005). Water quality. Determination of ammonium nitrogen. Method by flow analysis (CFA and FIA) and spectrometric detection (ISO 11732:2005). Finnish Standards Association.

SFS-EN ISO 13395:en. (1997). Water quality. Determination of nitrite nitrogen and nitrate nitrogen and the sum of both by flow analysis (CFA and FIA) and spectrometric detection (ISO 13395:1996). Finnish Standards Association.

Šimek, M., Virtanen, S., Krištůfek, V., Simojoki, A., \& Yli-Halla, M. (2011). Evidence of rich microbial communities in the subsoil of a boreal acid sulphate soil conducive to greenhouse gas emissions. Agriculture, Ecosystems \& Environment, 140, 113-122.

Šimek, M., Virtanen, S., Simojoki, A., Chroňáková, A., Elhottová, D., Krištůfek, V., \& Yli-Halla, M. (2014). The microbial communities and potential greenhouse gas production in boreal acid sulphate, non-acid sulphate, and reedy sulphidic soils. Science of the Total Environment, 466, 663-672.
Sohlenius, G., \& Öborn, I. (2004). Geochemistry and partitioning of trace metals in acid sulphate soils in Sweden and Finland before and after sulphide oxidation. Geoderma, 122, 167-175.

Soil Survey Staff. (2014). Keys to soil taxonomy (12th ed.). Washington, DC: USDA-Natural Resources Conservation Service.

Syväsalo, E., Regina, K., Turtola, E., Lemola, R., \& Esala, M. (2006). Fluxes of nitrous oxide and methane, and nitrogen leaching from organically and conventionally cultivated sandy soil in western Finland. Agriculture, Ecosystems \& Environment, 113, 342-348.

Taghizadeh-Toosi, A., Elsgaard, L., Clough, T. J., Labouriau, R., Ernstsen, V., \& Petersen, S. O. (2019). Regulation of $\mathrm{N}_{2} \mathrm{O}$ emissions from acid organic soil drained for agriculture. Biogeosciences, 16, 4555-4575.

Tattari, S., Koskiaho, J., Kosunen, M., Lepisto, A., Linjama, J., \& Puustinen, M. (2017). Nutrient loads from agricultural and forested areas in Finland from 1981 up to 2010 - can the efficiency of undertaken water protection measures seen? Environmental Monitoring and Assessment, 189, 95.

Thomsen, J. K., Geest, T., \& Cox, R. P. (1994). Mass spectrometric studies of the effect of $\mathrm{pH}$ on the accumulation of intermediates in denitrification by Paracoccus denitrificans. Applied and Environmental Microbiology, 60, 536-541.

Toivonen, J., \& Österholm, P. (2011). Characterization of acid sulfate soils and assessing their impact on a humic boreal lake. Journal of Geochemical Exploration, 110, 107-117.

Turtola, E., \& Paajanen, A. (1995). Influence of improved subsurface drainage on phosphorus losses and nitrogen leaching from a heavy clay soil. Agricultural Water Management, 28, 295-310.

Vaclavkova, S., Jørgensen, C. J., Jacobsen, O. S., Aamand, J., \& Elberling, B. (2014). The importance of microbial iron sulfide oxidation for nitrate depletion in anoxic Danish sediments. Aquatic Geochemistry, 20, 419-435.

Virtanen, S. (2015). Redox reactions and water quality in cultivated boreal acid sulphate soils in relation to water management. Academic Dissertation. University of Helsinki, Faculty of Agriculture and Forestry.

Virtanen, S., Uusi-Kämppä, J., Österholm, P., Bonde, A., \& YliHalla, M. (2016). Potential of controlled drainage and subirrigation to manipulate groundwater table for mitigating acid loadings in Finnish acid sulfate soils. In J. F. Strock (Ed.), Proceedings of the $10^{\text {th }}$ International Drainage Symposium, 7-9 September, 2016, Minneapolis, Minnesota (pp. 308314). St Joseph: American Society of Agricultural and Biological Engineers ASABE.

Wesström, I., Joel, A., \& Messing, I. (2014). Controlled drainage and sub-irrigation - a water management option to reduce non-point source pollution from agricultural land. Agriculture, Ecosystems \& Environment, 198, 74-82.

Woli, K. P., David, M. B., Cooke, R. A., McIsaac, G. F., \& Mitchell, C. A. (2010). Nitrogen balance in and export from agricultural fields associated with controlled drainage systems and denitrifying bioreactors. Ecological Engineering, $36,1558-1566$.

Zhu-Barker, X., Cavazos, A. R., Ostrom, N. E., Howarth, W. R., \& Glass, J. B. (2015). The importance of abiotic reactions for nitrous oxide production. Biogeochemistry, 126, 251-267. 